4

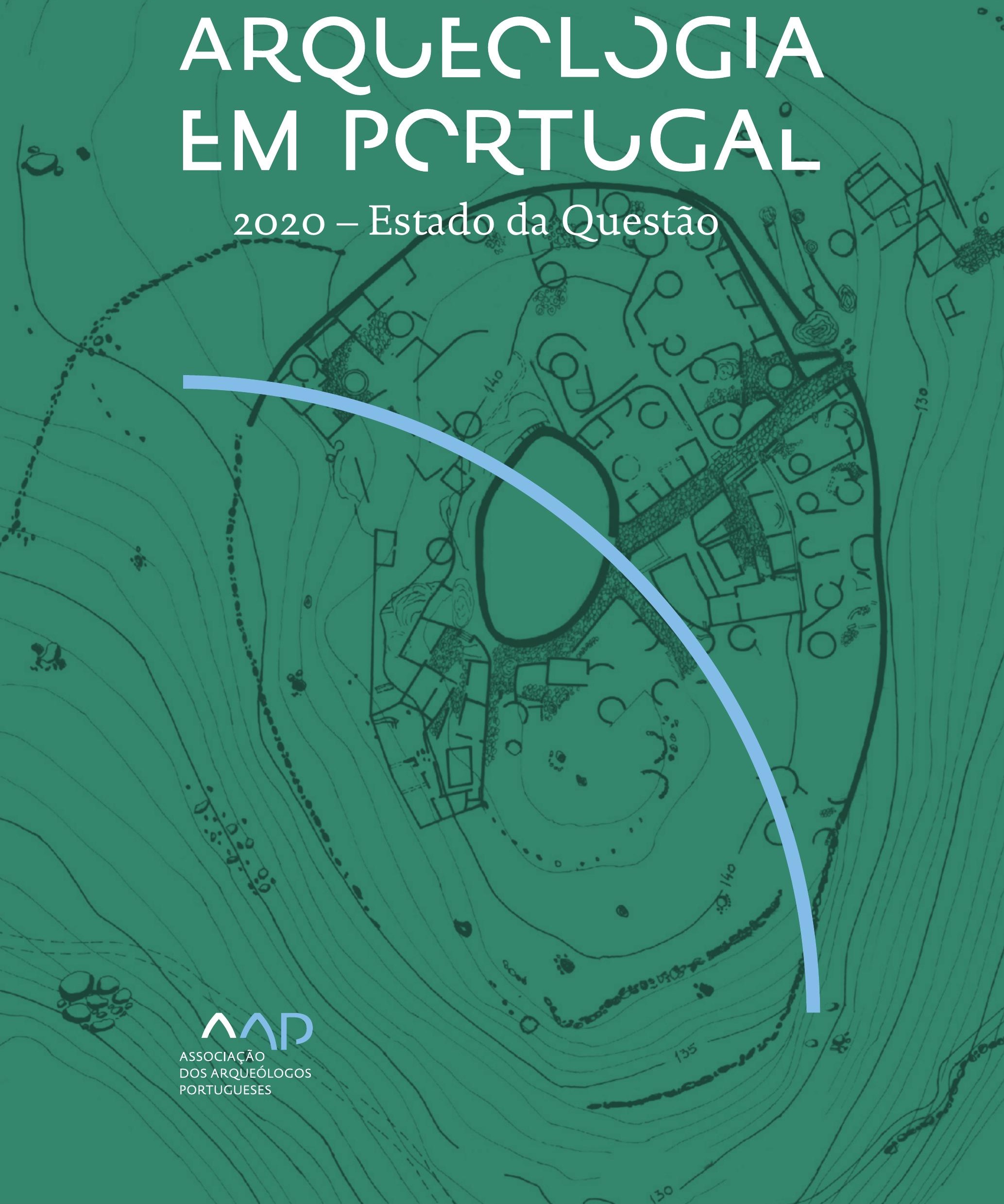


Coordenação editorial: José Morais Arnaud, César Neves e Andrea Martins Design gráfico: Flatland Design

AAP - ISBN: 978-972-9451-89-8

CITCEM - ISBN: 978-989-8970-25-1

Associação dos Arqueólogos Portugueses e CITCEM

Lisboa, 2020

O conteúdo dos artigos é da inteira responsabilidade dos autores. Sendo assim a Associação dos Arqueólogos Portugueses declina qualquer responsabilidade por eventuais equívocos ou questões de ordem ética e legal.

Desenho de capa:

Planta do castro de Monte Mozinho (Museu Municipal de Penafiel).

\section{$\hat{\wedge} \mathrm{P}$}

DOS ARQUEÓLOGOS PORTUGUESES

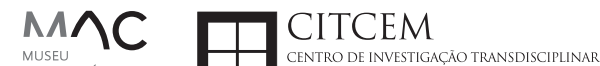
MUSEU
ARQUELLÓGICO
DO CARMO
U.PORTO

FLUP FACULDADE DE LETRAS
UNIVERSIDADE DO PORTO

Apoio

EC para a Ciência 


\section{Índice}

15 Prefácio

José Morais Arnaud

\section{Historiografia e Teoria}

17 Território, comunidade, memória e emoção: a contribuição da história da arqueologia (algumas primeiras e breves reflexões)

Ana Cristina Martins

25 Como descolonizar a arqueologia portuguesa?

Rui Gomes Coelho

41 Arqueologia e Modernidade: uma revisitação pessoal e breve de alguns aspetos da obra homónima de Julian Thomas de 2004

Vítor Oliveira Jorge

57 Dados para a História das Mulheres na Arqueologia portuguesa, dos finais do século XIX aos inícios do século XX: números, nomes e tabelas

Filipa Dimas / Mariana Diniz

73 Retractos da arqueologia portuguesa na imprensa: (in)visibilidades no feminino

Catarina Costeira / Elsa Luís

85 Arqueologia e Arqueólogos no Norte de Portugal Jacinta Bugalhão

101 Vieira Guimarães (1864-1939) e a arqueologia em Tomar: uma abordagem sobre o território e as gentes

João Amendoeira Peixoto / Ana Cristina Martins

115 Os memoráveis? A arqueologia algarvia na imprensa nacional e regional na presente centúria (2001-2019): características, visões do(s) passado(s) e a arqueologia

enquanto marca

Frederico Agosto / João Silva

129 A Evolução da Arqueologia Urbana e a Valorização Patrimonial no Barlavento Algarvio: Os casos de Portimão e Silves

Artur Mateus / Diogo Varandas / Rafael Boavida

\section{Gestão, Valorização e Salvaguarda do Património}

145 O Caderno Reivindicativo e as condições de trabalho em Arqueologia Miguel Rocha / Liliana Matias Carvalho / Regis Barbosa / Mauro Correia / Sara Simões / Jacinta Bugalhão / Sara Brito / Liliana Veríssimo Carvalho / Richard Peace / Pedro Peça / Cézer Santos

155 Os Estudos de Impacte Patrimonial como elemento para uma estratégia sustentável de minimização de impactes no âmbito de reconversões agrícolas Tiago do Pereiro

165 Salvaguarda de Património arqueológico em operações florestais: gestão e sensibilização Filipa Bragança / Gertrudes Zambujo / Sandra Lourenço / Belém Paiva / Carlos Banha / Frederico Tatá Regala / Helena Moura / Jacinta Bugalhão / João Marques / José Correia / Pedro Faria / Samuel Melro

179 Os valores do Património: uma investigação sobre os Sítios Pré-históricos de Arte Rupestre do Vale do Rio Côa e de Siega Verde José Paulo Francisco 
189 Conjugando recursos arqueológicos e naturais para potenciar as visitas ao Geoparque Litoral de Viana do Castelo (Noroeste de Portugal)

Hugo A. Sampaio / Ana M.S. Bettencourt / Susana Marinho / Ricardo Carvalhido

203 Áreas de Potencial Arqueológico na Região do Médio Tejo: Modelo Espacial Preditivo Rita Ferreira Anastácio / Ana Filipa Martins / Luiz Oosterbeek

223 Património Arqueológico e Gestão Territorial: O contributo da Arqueologia para a revisão do PDM de Avis

Ana Cristina Ribeiro

237 A coleção arqueológica do extinto Museu Municipal do Porto - Origens, Percursos e Estudos

Sónia Couto

251 Valpaços - uma nova carta arqueológica

Pedro Pereira / Maria de Fátima Casares Machado

263 Arqueologia na Cidade de Peniche

Adriano Constantino / Luís Rendeiro

273 Arqueologia Urbana: a cidade de Lagos como caso de Estudo Cátia Neto

285 Estratégias de promoção do património cultural subaquático nos Açores. O caso da ilha do Faial

José Luís Neto / José Bettencourt / Luís Borges / Pedro Parreira

297 Carta Arqueológica da Cidade Velha: Uma primeira abordagem

Jaylson Monteiro / Nireide Tavares / Sara da Veiga / Claudino Ramos / Edson Brito /

Carlos Carvalho / Francisco Moreira / Adalberto Tavares

311 Antropologia Virtual: novas metodologias para a análise morfológica e funcional Ricardo Miguel Godinho / Célia Gonçalves

\section{Didáctica da Arqueologia}

327 Como os projetos de Arqueologia podem contribuir para uma comunidade culturalmente mais consciente Alexandra Figueiredo / Claúdio Monteiro / Adolfo Silveira / Ricardo Lopes

337 Educação Patrimonial - Um cidadão esclarecido é um cidadão ativo! Ana Paula Almeida

351 A aproximação da Arqueologia à sala de aula: um caso de estudo no $3^{\circ}$ ciclo do Ensino Básico Luís Serrão Gil

363 Arqueologia 3.o - Pensar e comunicar a Arqueologia para um futuro sustentável Mónica Rolo

377 “Conversa de Arqueólogos" - Divulgar a Arqueologia em tempos de Pandemia Diogo Teixeira Dias

389 Escola Profissional de Arqueologia: desafios e oportunidades Susana Nunes / Dulcineia Pinto / Júlia Silva / Ana Mascarenhas

399 Os Museus de Arqueologia e os Jovens: a oferta educativa para o público adolescente Beatriz Correia Barata / Leonor Medeiros

411 O museu universitário como mediador entre a ciência e a sociedade: o exemplo da secção de arqueologia no Museu de História Natural e da Ciência da Universidade do Porto (MHNC-UP)

Rita Gaspar 
421 Museu de Lanifícios: Real Fábrica de Panos. Atividades no âmbito da Arqueologia Beatriz Correia Barata / Rita Salvado

427 Arqueologia Pública e o caso da localidade da Mata (Torres Novas) Cláudia Manso / Ana Rita Ferreira / Cristiana Ferreira / Vanessa Cardoso Antunes

431 Do sítio arqueológico ao museu: um percurso (também) didático Lídia Fernandes

447 Estão todos convidados para a Festa! E para dançar também... O projecto do Serviço Educativo do Museu Arqueológico do Carmo na $5^{\underline{a}}$ Edição da Festa da Arqueologia Rita Pires dos Santos

459 O “Clã de Carenque”, um projeto didático de arqueologia Eduardo Gonzalez Rocha

469 Mediação cultural: peixe que puxa carroça nas Ruínas Romanas de Troia Inês Vaz Pinto / Ana Patrícia Magalhães / Patrícia Brum / Filipa Santos

481 Didática Arqueológica, experiências do Projeto Mértola Vila Museu Maria de Fátima Palma / Clara Rodrigues / Susana Gómez / Lígia Rafael

\section{Arte Rupestre}

497 Os inventários de arte rupestre em Portugal Mila Simões de Abreu

513 O projeto FIRST-ART - conservação, documentação e gestão das primeiras manifestações de arte rupestre no Sudoeste da Península Ibérica: as grutas do Escoural e Maltravieso Sara Garcês / Hipólito Collado / José Julio García Arranz / Luiz Oosterbeek / António Carlos Silva / Pierluigi Rosina / Hugo Gomes / Anabela Borralheiro Pereira / George Nash / Esmeralda Gomes / Nelson Almeida / Carlos Carpetudo

523 Trabalhos de documentação de arte paleolítica realizados no âmbito do projeto PalæoCôa André Tomás Santos / António Fernando Barbosa / Luís Luís / Marcelo Silvestre / Thierry Aubry

537 Imagens fantasmagóricas, silhuetas elusivas: as figuras humanas na arte do Paleolítico Superior da região do Côa Mário Reis

$55^{1}$ Os motivos zoomórficos representados nas placas de tear de Vila Nova de São Pedro (Azambuja, Portugal) Andrea Martins / César Neves / José M. Arnaud / Mariana Diniz

571 Arte Rupestre do Monte de Góios (Lanhelas, Caminha). Síntese dos resultados dos trabalhos efectuados em 2007-2009 Mário Varela Gomes

599 Gravuras rupestres de barquiformes no Monte de S. Romão, Guimarães, Noroeste de Portugal Daniela Cardoso

613 Círculos segmentados gravados na Bacia do Rio Lima (Noroeste de Portugal): contributos para o seu estudo Diogo Marinho / Ana M.S. Bettencourt / Hugo Aluai Sampaio

631 Equídeos gravados no curso inferior do Rio Mouro, Monção (NW Portugal). Análise preliminar Coutinho, L.M. / Bettencourt, A.M.S / Sampaio, Hugo A.S

645 Paletas na Arte Rupestre do Noroeste de Portugal. Inventário preliminar Bruna Sousa Afonso / Ana M. S. Bettencourt / Hugo A. Sampaio 


\section{Pré-História}

661 O projeto Miño/Minho: balanço de quatro anos de trabalhos arqueológicos Sérgio Monteiro-Rodrigues / João Pedro Cunha-Ribeiro / Eduardo Méndez-Quintas / Carlos Ferreira / Pedro Xavier / José Meireles / Alberto Gomes / Manuel Santonja / Alfredo Pérez-González

677 A ocupação paleolítica da margem esquerda do Baixo Minho: a indústria lítica do sítio de Pedreiras 2 (Monção, Portugal) e a sua integração no contexto regional Carlos Ferreira / João Pedro Cunha-Ribeiro / Sérgio Monteiro-Rodrigues / Eduardo Méndez-Quintas / Pedro Xavier / José Meireles / Alberto Gomes / Manuel Santonja / Alfredo Pérez-González

693 O sítio acheulense do Plistocénico médio da Gruta da Aroeira Joan Daura / Montserrat Sanz / Filipa Rodrigues / Pedro Souto / João Zilhão

703 As sociedades neandertais no Barlavento algarvio: modelos preditivos com recurso aos SIG

Daniela Maio

715 A utilização de quartzo durante o Paleolítico Superior no território dos vales dos rios Vouga e Côa

Cristina Gameiro / Thierry Aubry / Bárbara Costa / Sérgio Gomes / Luís Luís / Carmen Manzano / André Tomás Santos

733 Uma perspetiva diacrónica da ocupação do concheiro do Cabeço da Amoreira (Muge, Portugal) a partir da tecnologia lítica Joana Belmiro / João Cascalheira / Célia Gonçalves

745 Novos dados sobre a Pré-história Antiga no concelho de Palmela. A intervenção arqueológica no sítio do Poceirão I

Michelle Teixeira Santos

757 Problemas em torno de Datas Absolutas Pré-Históricas no Norte do Alentejo Jorge de Oliveira

771 Povoamento pré-histórico nas áreas montanhosas do NO de Portugal: o Abrigo 1 de Vale de Cerdeira Pedro Xavier / José Meireles / Carlos Alves

783 Apreciação do povoamento do Neolítico Inicial na Baixa Bacia do Douro. A Lavra I (Serra da Aboboreira) como caso de estudo Maria de Jesus Sanches

797 O Processo de Neolitização na Plataforma do Mondego: os dados do Sector C do Outeiro dos Castelos de Beijós (Carregal do Sal)

João Carlos de Senna-Martinez / José Manuel Quintã Ventura / Andreia Carvalho / Cíntia Maurício

823 Novos trabalhos na Lapa da Bugalheira (Almonda, Torres Novas) Filipa Rodrigues / Pedro Souto / Artur Ferreira / Alexandre Varanda / Luís Gomes / Helena Gomes / João Zilhão

837 A pedra polida e afeiçoada do sítio do Neolítico médio da Moita do Ourives (Benavente, Portugal)

César Neves

857 Casal do Outeiro (Encarnação, Mafra): novos contributos para o conhecimento do povoamento do Neolítico final na Península de Lisboa.

Cátia Delicado / Carlos Maneira e Costa / Marta Miranda / Ana Catarina Sousa

873 Stresse infantil, morbilidade e mortalidade no sítio arqueológico do Neolítico Final/ Calcolítico ( $4^{\circ}$ e $3^{\circ}$ milénio a.C.) do Monte do Carrascal 2 (Ferreira do Alentejo, Beja) Liliana Matias de Carvalho / Sofia N. Wasterlain 
885 Come together: O Conjunto Megalítico das Motas (Monção, Viana do Castelo) e as expressões Campaniformes do Alto Minho Ana Catarina Basílio / Rui Ramos

899 Trabalhos arqueológicos no sítio Calcolítico da Pedreira do Poio Carla Magalhães / João Muralha / Mário Reis / António Batarda Fernandes

913 O sítio arqueológico de Castanheiro do Vento. Da arquitectura do sítio à arquitectura de um território João Muralha Cardoso

925 Estudo zooarqueológico das faunas do Calcolítico final de Vila Nova de São Pedro (Azambuja, Portugal): Campanhas de 2017 e 2018 Cleia Detry / Ana Catarina Francisco / Mariana Diniz / Andrea Martins / César Neves / José Morais Arnaud

943 As faunas depositadas no Museu Arqueológico do Carmo provenientes de Vila Nova de São Pedro (Azambuja): as campanhas de 1937 a 1967 Ana Catarina Francisco / Cleia Detry / César Neves / Andrea Martins / Mariana Diniz / José Morais Arnaud

959 Análise funcional de material lítico em sílex do castro de Vila Nova de S. Pedro (Azambuja, Portugal): uma primeira abordagem Rafael Lima

971 O recinto da Folha do Ouro 1 (Serpa) no contexto dos recintos de fossos calcolíticos alentejanos

António Carlos Valera / Tiago do Pereiro / Pedro Valério / António M. Monge Soares

\section{Proto-História}

987 Produção de sal marinho na Idade do Bronze do noroeste Português. Alguns dados para uma reflexão

Ana M. S. Bettencourt / Sara Luz / Nuno Oliveira / Pedro P. Simões / Maria Isabel C. Alves / Emílio Abad-Vidal

1001 A estátua-menir do Pedrão ou de São Bartolomeu do Mar (Esposende, noroeste de Portugal) no contexto arqueológico da fachada costeira de entre os rios Neiva e Cávado Ana M. S. Bettencourt / Manuel Santos-Estévez / Pedro Pimenta Simões / Luís Gonçalves

1015 O Castro do Muro (Vandoma/Baltar, Paredes) - notas para uma biografia de ocupação da Idade do Bronze à Idade Média

Maria Antónia D. Silva / Ana M. S. Bettencourt / António Manuel S. P. Silva / Natália Félix

1031 Do Bronze Final à Idade Média - continuidades e hiatos na ocupação de Povoados em Oliveira de Azeméis João Tiago Tavares / Adriaan de Man

1041 As faunas do final da Idade do Bronze no Sul de Portugal: leituras desde o Outeiro do Circo (Beja)

Nelson J. Almeida / Íris Dias / Cleia Detry / Eduardo Porfírio / Miguel Serra

1055 A Espada do Monte das Oliveiras (Serpa) - uma arma do Bronze Pleno do Sudoeste Rui M. G. Monge Soares / Pedro Valério / Mariana Nabais / António M. Monge Soares

1065 São Julião da Branca (Albergaria-a-Velha) - Investigação e valorização de um povoado do Bronze Final

António Manuel S. P. Silva / Paulo A. P. Lemos / Sara Almeida e Silva / Edite Martins de Sá

1083 Do castro de S. João ao Mosteiro de Santa Clara: notícia de uma intervenção arqueológica, em Vila do Conde Rui Pinheiro 
1095 O castro de Ovil (Espinho), um quarto de século de investigação - resultados e questões em aberto

Jorge Fernando Salvador / António Manuel S. P. Silva

1111 O Castro de Salreu (Estarreja), um povoado proto-histórico no litoral do Entre Douro e Vouga

Sara Almeida e Silva / António Manuel S. P. Silva / Paulo A. P. Lemos / Edite Martins de Sá

1127 Castro de Nossa Senhora das Necessidades (Sernancelhe): uma primeira análise artefactual Telma Susana O. Ribeiro

${ }_{1141}$ A cividade de Bagunte. O estado atual da investigação Pedro Brochado de Almeida

1153 Zoomorfos na cerâmica da Idade do Ferro no NW Peninsular: inventário, cronologias e significado Nuno Oliveira / Cristina Seoane

1163 Vasos gregos em Portugal: diferentes maneiras de contar a história do intercâmbio cultural na Idade do Ferro

Daniela Ferreira

1175 Os exotica da necrópole da Idade do Ferro do Olival do Senhor dos Mártires (Alcácer do Sal) no seu contexto regional

Francisco B. Gomes

\section{Antiguidade Clássica e Tardia}

1191 O uso de madeira como combustível no sítio da Quinta de Crestelos (Baixo Sabor): da Idade do Ferro à Romanização Filipe Vaz / João Tereso / Sérgio Simões Pereira / José Sastre / Javier Larrazabal Galarza / Susana Cosme / José António Pereira / Israel Espi

1207 Cultivos de Época Romana no Baixo Sabor: continuidade em tempos de mudança? João Pedro Tereso / Sérgio Simões Pereira / Filipe Santos / Luís Seabra / Filipe Vaz

1221 A casa romana na Hispânia: aplicação dos modelos itálicos nas províncias ibéricas Fernanda Magalhães / Diego Machado / Manuela Martins

1235 As pinturas murais romanas da Rua General Sousa Machado, n. ${ }^{5}$ 1, Chaves José Carvalho

1243 Trás do Castelo (Vale de Mir, Pegarinhos, Alijó) - Uma exploração agrícola romana do Douro

Tony Silvino / Pedro Pereira

1255 A sequência de ocupação no quadrante sudeste de Bracara Augusta: as transformações de uma unidade doméstica Lara Fernandes / Manuela Martins

1263 Os Mosaicos com decoração geométrica e geométrico-vegetalista dos sítios arqueológicos da área do Conuentus Bracaraugustanus. Novas abordagens quanto à conservação, restauro, decoração e datação Maria de Fátima Abraços / Licínia Wrench

1277 “Casa Romana” do Castro de São Domingos (Cristelos, Lousada): Escavação, Estudo e Musealização Paulo André de P. Lemos

1291 A arqueobotânica no Castro de Guifões (Matosinhos, Noroeste de Portugal): O primeiro estudo carpológico

Luís Seabra / Andreia Arezes / Catarina Magalhães / José Varela / João Pedro Tereso 
1305 Um Horreum Augustano na Foz do Douro (Monte do Castelo de Gaia, Vila Nova de Gaia) Rui Ramos

1311 Ponderais romanos na Lusitânia: padrões, formas, materiais e contextos de utilização Diego Barrios Rodríguez

1323 Um almofariz centro-itálico na foz do Mondego

Marco Penajoia

1335 Estruturas romanas de Carnide - Lisboa Luísa Batalha / Mário Monteiro / Guilherme Cardoso

1347 O contexto funerário do sector da "necrópole NO" da Rua das Portas de S. Antão (Lisboa): o espaço, os artefactos, os indivíduos e a sua interconectividade na interpretação do passado Sílvia Loja, José Carlos Quaresma, Nelson Cabaço, Marina Lourenço, Sílvia Casimiro, Rodrigo Banha da Silva, Francisca Alves-Cardoso

${ }_{1361}$ Povoamento em época Romana na Amadora - resultados de um projeto pluridisciplinar Gisela Encarnação / Vanessa Dias

1371 A Arquitectura Residencial em Mirobriga (Santiago do Cacém): contributo a partir de um estudo de caso Filipe Sousa / Catarina Felício

${ }_{1385}$ O fim do ciclo. Saneamento e gestão de resíduos nos edifícios termais de Mirobriga (Santiago do Cacém)

Catarina Felício / Filipe Sousa

1399 Balsa, Topografia e Urbanismo de uma Cidade Portuária Vítor Silva Dias / João Pedro Bernardes / Celso Candeias / Cristina Tété Garcia

1413 No Largo das Mouras Velhas em Faro (2017): novas evidências da necrópole norte de Ossonoba e da sua ocupação medieval Ricardo Costeira da Silva / Paulo Botelho / Fernando Santos / Liliana Nunes

1429 Instrumentos de pesca recuperados numa fábrica de salga em Ossonoba (Faro) Inês Rasteiro / Ricardo Costeira da Silva / Paulo Botelho

1439 A Necrópole Romana do Eirô, Duas Igrejas (Penafiel): intervenção arqueológica de 2016 Laura Sousa / Teresa Soeiro

1457 Ritual, descarte ou afetividade? A presença de Canis lupus familiaris na Necrópole Noroeste de Olisipo (Lisboa)

Beatriz Calapez Santos / Sofia Simões Pereira / Rodrigo Banha da Silva / Sílvia Casimiro / Cleia Detry / Francisca Alves Cardoso

1467 Dinâmicas económicas em Bracara na Antiguidade Tardia Diego Machado / Manuela Martins / Fernanda Magalhães / Natália Botica

1479 Cerâmicas e Vidros da Antiguidade Tardia do Edifício sob a Igreja do Bom Jesus (Vila Nova de Gaia) Joaquim Filipe Ramos

1493 Novos contributos para a topografia histórica de Mértola no período romano e na Antiguidade Tardia Virgílio Lopes

\section{8. Época Medieval}

1511 Cerâmicas islâmicas no Garb setentrional "português": algumas evidências e incógnitas Constança dos Santos / Helena Catarino / Susana Gómez / Maria José Gonçalves / Isabel Inácio / Gonçalo Lopes / Jacinta Bugalhão / Sandra Cavaco / Jaquelina Covaneiro / Isabel Cristina Fernandes / Ana Sofia Gomes 
1525 Contributo para o conhecimento da cosmética islâmica, em Silves, durante a Idade Média Rosa Varela Gomes

1537 Yábura e o seu território - uma análise histórico-arqueológica de Évora entre os séculos VIII-XII José Rui Santos

1547 A encosta sul do Castelo de Palmela - resultados preliminares da escavação arqueológica Luís Filipe Pereira / Michelle Teixeira Santos

1559 A igreja de São Lourenço (Mouraria, Lisboa): um conjunto de silos e de cerâmica medieval islâmica

Andreia Filipa Moreira Rodrigues

1571 O registo material de movimentações populacionais no Médio Tejo, durante os séculos XII-XIII. Dois casos de "sunken featured buildings", nos concelhos de Cartaxo e Torres Novas Marco Liberato / Helena Santos / Nuno Santos

1585 O nordeste transmontano nos alvores da Idade média. Notas para reflexão Ana Maria da Costa Oliveira

1601 Sepulturas escavadas na rocha do Norte de Portugal e do Vale do Douro: primeiros resultados do Projecto SER-NPVD

Mário Jorge Barroca / César Guedes / Andreia Arezes / Ana Maria Oliveira

1619 "Portucalem Castrum Novum" entre o Mediterrâneo e o Atlântico: o estudo dos materiais cerâmicos alto-medievais do arqueossítio da rua de D. Hugo, nํ. 5 (Porto) João Luís Veloso

1627 A Alta Idade Média na fronteira de Lafões: notas preliminares sobre a Arqueologia no Concelho de Vouzela

Manuel Luís Real / Catarina Tente

1641 Um conjunto cerâmico medieval fora de portas: um breve testemunho aveirense Susana Temudo

${ }_{1651}$ Os Lóios do Porto: uma perspetiva integrada no panorama funerário da Baixa Idade Média à Época Moderna em meios urbanos em Portugal

Ana Lema Seabra

1659 O Caminho Português Interior de Santiago como eixo viário na Idade Média Pedro Azevedo

1665 Morfologia Urbana: Um exercício em torno do Castelo de Ourém André Donas-Botto / Jaqueline Pereira

1677 Intervenção arqueológica na Rua Marquês de Pombal/Largo do Espírito Santo (Bucelas, Loures)

Florbela Estêvão / Nathalie Antunes-Ferreira / Dário Ramos Neves / Inês Lisboa

1691 O Cemitério Medieval do Poço do Borratém e a espacialidade funerária na cidade de Lisboa Inês Belém / Vanessa Filipe / Vasco Noronha Vieira / Sónia Ferro / Rodrigo Banha da Silva

1705 Um Espaço Funerário Conventual do séc. XV em Lisboa: o caso do Convento de São Domingos da Cidade Sérgio Pedroso / Sílvia Casimiro / Rodrigo Banha da Silva / Francisca Alves Cardoso

\section{9. Época Moderna e Contemporânea}

1721 Arqueologia Moderna em Portugal: algumas reflexões críticas em torno da quantificação de conjuntos cerâmicos e suas inferências históricas e antropológicas Rodrigo Banha da Silva / André Bargão / Sara da Cruz Ferreira

1733 Faianças de dois contextos entre os finais do século XVI e XVIII do Palácio dos Condes de Penafiel, Lisboa

Martim Lopes / Tomás Mesquita 
1747 Um perfil de consumo do século XVIII na foz do Tejo: O caso do Mercado da Ribeira, Lisboa Sara da Cruz Ferreira / Rodrigo Banha da Silva / André Bargão

1761 Os Cachimbos dos Séculos XVII e XVIII do Palácio Mesquitela e Convento dos Inglesinhos (Lisboa)

Inês Simão / Marina Pinto / João Pimenta / Sara da Cruz Ferreira / André Bargão / Rodrigo Banha da Silva

1775 "Tomar os fumos da erua que chamão em Portugal erua sancta». Estudo de Cachimbos provenientes da Rua do Terreiro do Trigo, Lisboa

Miguel Martins de Sousa / José Pedro Henriques / Vanessa Galiza Filipe

1787 Cachimbos de Barro Caulínitico da Sé da Cidade Velha (República de Cabo Verde)

Rodrigo Banha da Silva / João Pimenta / Clementino Amaro

1801 Algumas considerações sobre espólio não cerâmico recuperado no Largo de Jesus (Lisboa) Carlos Boavida

1815 Adereços de vidro, dos séculos XVI-XVIII, procedentes do antigo Convento de Santana de Lisboa (anéis, braceletes e contas)

Joana Gonçalves / Rosa Varela Gomes / Mário Varela Gomes

1837 Da ostentação, luxo e poder à simplicidade do uso quotidiano: arqueologia e simbologia de joias e adornos da Idade Moderna Portuguesa Jéssica Iglésias

1849 Os amuletos em Portugal - dos objetos às superstições: o coral vermelho Alexandra Vieira

1865 Cerâmicas de Vila Franca de Xira nos séculos XV e XVI Eva Pires

1879 «Não passa por teu o que me pertence». Marcas de individualização associadas a faianças do Convento de Nossa Senhora de Aracoeli, Alcácer do Sal Catarina Parreira / Íris Fragoso / Miguel Martins de Sousa

1891 Cerâmica de Leiria: alguns focos de produção

Jaqueline Pereira / André Donas-Botto

1901 Os Fornos na Rua da Biquinha, em Óbidos Hugo Silva / Filipe Oliveira

1909 A casa de Pêro Fernandes, contador dos contos de D. Manuel I: o sítio arqueológico da Silha do Alferes, Seixal (século XVI) Mariana Nunes Ferreira

1921 O Alto da Vigia (Sintra) e a vigilância e defesa da costa Alexandre Gonçalves / Sandra Santos

1937 O contexto da torre sineira da Igreja de Santa Maria de Loures Paulo Calaveira / Martim Lopes

1949 A Necrópole do Hospital Militar do Castelo de São Jorge e as práticas funerárias na Lisboa de Época Moderna Susana Henriques / Liliana Matias de Carvalho / Ana Amarante / Sofia N. Wasterlain

1963 SAND - Sarilhos Grandes Entre dois Mundos: o adro da Igreja e a Paleobiologia dos ossos humanos recuperados

Paula Alves Pereira / Roger Lee Jesus / Bruno M. Magalhães

1975 Expansão urbana da vila de Cascais no século XVII e XVIII: a intervenção arqueológica na Rua da Vitória no 15 a 17

Tiago Pereira / Vanessa Filipe

1987 Novos dados para o conhecimento do Urbanismo de Faro em época Moderna Ana Rosa 
1995 Um exemplo de Arqueologia Urbana em Alcoutim: o Antigo Edifício dos CTT Marco Fernandes / Marta Dias / Alexandra Gradim / Virgílio Lopes / Susana Gómez Martínez

2007 Palácio dos Ferrazes (Rua das Flores/Rua da Vitória, Porto): a cocheira de Domingos Oliveira Maia

Francisco Raimundo

2021 As muitas vidas de um edifício urbano: História, Arqueologia e Antropologia no antigo Recreatório Paroquial de Penafiel Helena Bernardo / Jorge Sampaio / Marta Borges

2035 O convento de Nossa Senhora da Esperança de Ponta Delgada: o contributo da arqueologia para o conhecimento de um monumento identitário João Gonçalves Araújo / N’Zinga Oliveira

2047 Arqueologia na ilha do Corvo... em busca da capela de Nossa Senhora do Rosário Tânia Manuel Casimiro / José Luís Neto / Luís Borges / Pedro Parreira

2059 Perdidos à vista da Costa. Trabalhos arqueológicos subaquáticos na Barra do Tejo Jorge Freire / José Bettencourt / Augusto Salgado

2071 Arqueologia marítima em Cabo Verde: enquadramento e primeiros resultados do projecto CONCHA

José Bettencourt / Adilson Dias / Carlos Lima / Christelle Chouzenoux / Cristóvão Fonseca / Dúnia Pereira / Gonçalo Lopes / Inês Coelho / Jaylson Monteiro / José Lima / Maria Eugénia Alves / Patrícia Carvalho / Tiago Silva

2085 Trabalhos arqueológicos na Cidade Velha (Ribeira Grande de Santiago, Cabo Verde): reflexões sobre um projecto de investigação e divulgação patrimonial André Teixeira / Jaylson Monteiro / Mariana Mateus / Nireide Tavares / Cristovão Fonseca / Gonçalo C. Lopes / Joana Bento Torres / Dúnia Pereira / André Bargão / Aurélie Mayer / Bruno Zélie / Carlos Lima / Christelle Chouzenoux / Inês Henriques / Inês Pinto Coelho / José Lima / Patrícia Carvalho / Tiago Silva

2103 A antiga fortificação de Quelba / Khor Kalba (E.A.U.). Resultados de quatro campanhas de escavações, problemáticas e perspectivas futuras Rui Carita / Rosa Varela Gomes / Mário Varela Gomes / Kamyar Kamyad

2123 Colónias para homens novos: arqueologia da colonização agrária fascista no noroeste ibérico Xurxo Ayán Vila / José Mạ . Señorán Martín 


\title{
A PEDRA POLIDA E AFEIÇOADA DO SÍTIO DO NEOLÍTICO MÉDIO DA MOITA DO OURIVES (BENAVENTE, PORTUGAL)
}

\author{
César Neves ${ }^{1}$
}

RESUMO

Apresentação do conjunto de artefactos de pedra polida e afeiçoada identificado no sítio da Moita do Ourives. O universo artefactual é pouco expressivo com os exemplares em mau estado de conservação e elevado grau de fragmentação, dificultando a classificação tipológica e funcional. Para a sua produção, destacam-se os artefactos sobre matérias-primas localmente disponíveis, como o quartzito, arenito e o quartzo (85\% das ocorrências). As matérias-primas exógenas (anfibolito e granito), possivelmente obtidas a mais de 4okm do sítio, representam cerca de $15 \%$ dos elementos registados.

Apesar das limitações que dispõe, este estudo permite, em conjunto com os restantes elementos da cultura material, uma reflexão acerca da funcionalidade desta ocupação, bem como da mobilidade e actividades socioeconómicas das comunidades do Neolítico médio no ocidente Peninsular.

Palavras-chave: Moita do Ourives, Neolítico médio, Cultura material, Pedra polida, Pedra afeiçoada.

\begin{abstract}
Presentation of the polished and ground stone tools artefacts from Neolithic site of Moita do Ourives. It corresponds to a low number of artifacts in poor preservation condition and high degree of fragmentation, making the typological and functional classification quite difficult. The tools production is based mainly on locally available raw materials, such as quartzite, sandstone and quartz (85\% of the all set). Exogenous raw materials (amphibolite and granite), possibly obtained more than $40 \mathrm{~km}$ from the site, represent $15 \%$ of the recovered elements.

The results of this study allow, together with the analysis of other material culture elements, a reflection on the functionality of this settlement, as well as the mobility and socioeconomic activities of the communities of the Middle Neolithic in the Western Iberia.
\end{abstract}

Keywords: Moita do Ourives, Middle Neolithic, Material Culture, Polished and ground stone tools.

\section{INTRODUÇÃO}

O sítio da Moita do Ourives localiza-se na margem esquerda do Baixo vale do Tejo, tendo sido identificado em 2004 e alvo, até à data, de duas intervenções arqueológicas (Rodrigues, 2006; Neves et. al. 2008). Recentemente procedeu-se ao estudo integral dos dados provenientes destas escavações, o que permitiu integrar a ocupação de cariz doméstico num espaço crono-cultural denominado Neolítico médio pleno, entre o segundo e terceiro quartel do $4^{\circ}$ milénio AC (Neves, 2018).
A Moita do Ourives corresponde a uma estratégia de ocupação de um território "moldada" aos recursos naturais aí existentes, às condições de mobilidade que o mesmo permite, provavelmente integrada numa rede de povoamento que inclui sítios de outra natureza funcional e dimensão.

Ao nível dos recursos naturais, a ocupação terá tido em conta a grande proximidade com as ribeiras de Santo Estêvão, e os rios Almansor e Sorraia, afluentes de um curso principal, o Tejo, também ele, à data da ocupação, mais próximo do sítio arqueológico. Estes três elementos, o Tejo, Almansor e Sorraia

1. AAP - Associação dos Arqueólogos Portugueses; UNIARQ - Centro de Arqueologia da Universidade de Lisboa, Faculdade de Letras, Universidade de Lisboa; c.augustoneves@gmail.com 
- linhas de água com caudal expressivo devido à transgressão flandriana - bem como as vastas planícies que rodeavam a Moita do Ourives, permitiam aos grupos que aí habitavam, um ritmo de mobilidade efectivo, sem grandes condicionalismos geográficos, possibilitando a deslocação até territórios e contextos geológicos distintos - Estremadura e Alentejo interior - onde se encontrariam melhores condições para práticas agro-pastoris, bem como a existência de matérias-primas não disponíveis nas imediações da ocupação, numa necessária complementaridade que o modelo social, cultural e económico do processo de Neolitização, gradualmente, impunha.

A Moita do Ourives encontra-se num território que carece localmente de granito e rochas anfibólicas, matérias-primas tradicionalmente associadas ao registo arqueográfico de elementos de moagem e de pedra polida das comunidades neolíticas.

A presença no sítio, mesmo que escassa, de artefactos produzidos sobre estas matérias-primas apresentam-se como marcadores de proveniências a média e longa distância, contribuindo para a compreensão dos espaços de circulação, exploração de recursos e dinâmicas socioeconómicas das comunidades durante o Neolítico médio (Figura 1).

\section{PEDRA POLIDA E AFEIÇOADA DA MOITA DO OURIVES: APRESENTAÇÃO}

$\mathrm{Na}$ análise do conjunto da Moita do Ourives foram incluídos todos os artefactos de pedra polida, afeiçoada ou com traços de utilização recolhidos no decorrer das duas escavações arqueológicas, assim como um fragmento de granito, classificado como manuporte - uma vez que se trata de uma rocha que não existe no substrato geológico local, e cuja presença no sítio deverá ser intencional, logo considerada culturalmente significativa.

Incluíram-se os elementos cujo polimento corresponde ao objectivo pré-determinado de afeiçoar um instrumento funcional (pedra polida), assim como os objectos, cujo polimento/afeiçoamento corresponde a uma consequência da sua utilização (pedra afeiçoada) (Cardoso, 1999/2000, p.242).

A colecção é constituída por um número muito diminuto de elementos (21), apresentando, do ponto de vista tipológico e funcional, uma reduzida diversidade interna. O conjunto caracteriza-se pela presença de instrumentos acabados, estando praticamente au- sentes elementos que possam corresponder ao processo de produção desta utensilagem (Tabela 1).

Os elementos em análise provêm, na sua larga maioria, do nível arqueológico identificado nas duas áreas de escavação. Os artefactos registados em outras camadas, surgem no nível imediatamente superior, mostrando que o seu peso não terá permitido uma significativa dispersão vertical, mantendo-se, assim, próximos do nível de ocupação.

O mau estado de conservação e o elevado grau de fragmentação poderão estar relacionados com a intensidade e grau de utilização a que estes elementos estiveram sujeitos, tendo sido abandonados numa fase de completo esgotamento. Após o seu abandono ter-se-á verificado uma dispersão aleatória destes fragmentos pelo sítio, possivelmente sem qualquer relação com os espaços de uso. Além do grau de utilização, o estado de conservação destes artefactos também poderá estar relacionado com fenómenos pós-deposicionais contribuindo, de igual modo, para a sua desagregação. Apesar de não ser possível identificar, com toda a clareza, a existência de prováveis áreas funcionalmente especializadas, verificaram-se algumas situações, nomeadamente de associações espaciais entre artefactos (ex: movente e dormente).

\subsection{Critérios e objectivos da análise}

A ficha descritiva que serviu de suporte base à análise desta pequena colecção seguiu, no geral, os critérios de análise utilizados por Victor S. Gonçalves (Gonçalves, 1989), adoptando, também, alguns parâmetros descritivos da Ficha Descritiva apresentada por Mariana Diniz (Diniz, 2007, p.230 e 231). Os critérios e a nomenclatura referente à classificação específica dos artefactos de pedra polida, tendo em conta os atributos descritivos observados, segue a utilizada por João L. Cardoso (Cardoso, 1999/200o). A análise dos artefactos da Moita do Ourives seguiu os princípios da cadeia operatória, na tentativa de definir o contexto socioeconómico onde foram produzidos/utilizados/abandonados, focando-se nas seguintes temáticas:

\section{Matéria-prima}

- Inventário das matérias-primas presentes no conjunto;

- Identificar as áreas geográficas dos recursos explorados, definindo os possíveis espaços de origem das rochas e minerais, bem como a sua distância face à Moita do Ourives; 


\section{Utilização}

- Identificar possíveis indicadores de produção e utilização na Moita do Ourives;

\section{Classificação tipológica e funcional}

- Classificação, descrição e reflexão sobre possíveis funcionalidades específicas dos artefactos, individualizando-os pelas seguintes categorias: pedra polida, pedra afeiçoada e pedra com traços de utilização;

Para, posteriormente, se conseguir discutir e avaliar:

- Natureza e tipologia funcional da ocupação da Moita do Ourives;

- Caracterização do subsistema económico do grupo que ocupou o sítio;

- Existência de eventuais redes de troca e circulação, suas trajectórias, peso económico e social;

A Descrição e Classificação Tipológica continuam a ser uma componente essencial na análise destes objectos, uma vez que sem este passo (inicial), torna-se impossível quantificar, comparar e relacionar com outros contextos eventualmente análogos, assim como investigar a relação entre a morfologia do artefacto, a sua manufactura e reutilização, ajudando a detectar (ou não) eventuais variabilidades regionais e espaciais.

O conjunto da Moita do Ourives, que seguidamente se abordará, pretende, assim, estar disponível a integrar um quadro empírico, ainda diminuto, para o espaço crono-cultural em análise.

\subsection{Descrição e classificação do conjunto}

\section{Matérias-primas e áreas de proveniência}

A identificação das possíveis áreas de proveniência das matérias-primas, utilizadas na produção de utensilagem, é uma tarefa primordial na classificação tecno-tipológica da Cultura Material e decisiva na caracterização dos ritmos de interacção e estratégias de exploração do espaço dos grupos humanos neolíticos, no extremo Ocidente Peninsular.

Neste sentido, as leituras apresentadas para os artefactos da Moita do Ourives resultam da observação macroscópica dos mesmos, em termos de suas características geológicas. Assim, os dados apresentados não serão definitivos, mas permitem uma primeira reflexão acerca das trajectórias de obtenção das distintas matérias-primas, da sua selecção e a indicação das presumíveis zonas de proveniência, estabelecendo, assim, as bases conceptuais para futuras análises mais pormenorizadas.

$\mathrm{Na}$ Moita do Ourives, à imagem da indústria da pedra lascada, a indústria da pedra polida/afeiçoada e com traços de utilização assentou tendencialmente sobre matérias-primas localmente disponíveis. Com excepção do granito e do anfibolito, este último utilizado no único machado de pedra polida recolhido na intervenção, todas as outras rochas e minerais empregues existem nas imediações do sítio, ou num raio de poucos quilómetros (Figura 2).

A abundância, na região, de seixos de quartzito e arenito - rochas aptas para utilização directa ou afeiçoamento - permite a sua obtenção directa no território imediato de captação de recursos, apesar de não ter sido possível, até ao momento, definir com rigor esses espaços prováveis de proveniência, uma vez que não foram realizadas análises petrológicas sobre este material.

As cascalheiras existentes nos depósitos de terraços fluviais localizados nas imediações do sítio permitiam a obtenção, sem grande esforço, de seixos de quartzito (e quartzo, embora este em número muito residual), que serviram para criar utensílios relacionados com o talhe (percutores, martelo e bigorna), mas também para produção de elementos de moagem, como os moventes.

$\mathrm{O}$ arenito, exclusivamente utilizado na produção de elementos de mó - um dormente e dois fragmentos de moventes - corresponde a uma rocha de origem local/regional. Disponível nas formações sedimentares do Plio-Plistocénico e do Mio-Pliocénico, é possível recolher amostras de arenito nos depósitos de terraço, ao longo dos rios da bacia do Rio Tejo.

Os elementos artefactuais, em pedra polida e em pedra afeiçoada, produzidos em rochas de origem exógena correspondem a um machado, em anfibolito, e a um fragmento de movente, em granito.

A partir da Moita do Ourives, o anfibolito tem as suas fontes de aprovisionamento mais próximas no interior alentejano, nomeadamente nas formações sedimentares metamórficas do Complexo Precâmbrico da área de Montemor-o-Novo e Vendas Novas, situadas num raio mínimo de 40 a $50 \mathrm{~km}$. Um pouco mais distante, mas ainda no mesmo ambiente regional, surgem rochas anfibólicas na área de Arraiolos, Pavia, Évora e Viana do Alentejo (Carta Geológica de Portugal, 1992).

O outro espaço regional mais próximo da ocupação, 
onde se identificam fontes primárias desta matéria-prima, localiza-se na área de Montargil, Ponte de Sor e Mora, que dista cerca de $6 \mathrm{okm}$. Embora não esteja referida na carta litógica e geológica de Portugal, esta zona surge referenciada nos estudos de proveniência deste tipo de rocha, em outros contextos pré-históricos (Cardoso, 1999-200o, p. 266; Read, Grapes e Lillios, 1997, p.4). Outras áreas de possível proveniência, embora ainda mais distantes, situam-se na zona do médio Tejo (Abrantes e Gavião - c. de $8 \mathrm{okm})$, e na região mais próxima do nordeste alentejano, como Crato, Campo Maior e Elvas.

Relativamente ao granito, as suas possíveis áreas de proveniência não diferem muito do anfibolito, numa situação que não deixa de ser interessante na possível definição dos trajectos e áreas de circulação em que o grupo que ocupou a Moita do Ourives pode ter estado envolvido. As áreas mais próximas situam-se na região de Montemor-o-Novo e Vendas Novas, situadas num raio mínimo de 40 a $50 \mathrm{~km}$, ou no espaço situado a norte de Évora. Mais a norte da Moita do Ourives, estão registadas pequenas manchas de granito na região de Montargil e Ponte de Sor, que distam a cerca de $6 \mathrm{okm}$. As manchas de maior dimensão, e que ainda poderão se enquadrar no espaço de interacção desta comunidade, situam-se em áreas mais distantes como Portalegre, Elvas, Nisa e Castelo de Vide. Ainda no granito, importa referir a mancha localizada em Sintra a uma distância, em linha recta, de cerca de 5okm da Moita do Ourives.

Como se verá adiante, estes espaços regionais não seriam, somente, prováveis locais de captação de recursos e fontes de matérias-primas. A evidência empírica disponível para essas áreas regista a presença de ocupações domésticas e funerárias relacionadas com o Neolítico médio, presumivelmente contemporâneos da Moita do Ourives, nomeadamente na área de Évora e Montargil.

\section{Indicadores de produção e utilização local}

Perante um conjunto tão diminuto torna-se difícil tecer considerações sobre possíveis indicadores de produção local. O único artefacto de pedra polida que corresponde a um produto acabado em anfibolito apresenta, no seu gume, intensos traços de utilização. Não há, no entanto, outros elementos artefactuais desta matéria-prima, como blocos em bruto, polidores e/ou afiadores, assim como vestígios de produtos não acabados, que permitam demonstrar, de forma inequívoca, a produção destes artefactos no sítio. Por outro lado, o facto de se tratar de uma matéria-prima exógena, com origem a cerca de 40-50km de distância do sítio, seria pouco provável o transporte de blocos em bruto para, depois, se produzirem estes instrumentos, na Moita do Ourives. Os traços de utilização que o machado apresenta, bem como o seu grau de fragmentação, pode ser um bom indicador da sua utilização no local, ou nas redondezas mais imediatas.

Nos elementos de moagem surgem indícios mais consistentes de produção e utilização local. Além da maioria dos produtos ter origem em matérias-primas disponíveis nas imediações do sítio, existe uma elevada fragmentação dos mesmos que sugere um uso intensivo até ao seu esgotamento e, consequente, abandono. Aparentemente, este tipo de material terá sido produzido em contexto habitacional tendo sido, á́, utilizado e abandonado. A identificação de áreas destinadas ao exercício das actividades associadas a estes instrumentos carece de uma evidência empírica mais sólida, apesar de ocorrem algumas associações espaciais entre alguns instrumentos afeiçoados (Neves, 2018, p.318).

\section{Tipologia e funcionalidade}

\section{a) Pedra polida \\ Machado}

Relativamente à pedra polida, o conjunto artefactual da Moita do Ourives é composto por um único elemento. Seguindo o critério de classificar o artefacto pela morfologia da sua extremidade distal, isto é, a sua área funcional e útil (Cooney e Mandal, 1998; Le Roux, 1999), constatou-se que se trata de um machado.

O exemplar recuperado corresponde a um fragmento com a área mesial e distal conservada. Apresenta uma fractura dupla, perpendicular e paralela ao eixo maior da peça. Desconhece-se se o seu estado de conservação resulta, exclusivamente, da sua utilização como utensílio. No entanto, importa referir que apresenta um gume com intensos traços de uso, denotando um grau de utilização igualmente elevado. Trata-se de um fragmento com cerca de $72 \mathrm{~mm}$ de comprimento, $22 \mathrm{~mm}$ de largura e $35 \mathrm{~mm}$ de espessura conservada, pesando 66g. Possui secção sub-circular, bordos paralelos, um corpo ligeiramente polido e muito picotado, não sendo possível apurar a tipologia do talão. Quanto ao gume, este encontra- 
-se totalmente polido e convexo no que diz respeito à sua geometria (Figura 3, ํㅜㅍㅜ).

Quanto à sua funcionalidade, o facto de o número destes utensílios ser muito diminuto tem sido um entrave à realização de estudos funcionais e análises traceológicas, não muito comuns em artefactos desta natureza. Por outro lado, o facto de a larga maioria destes artefactos surgirem em contextos funerários, correspondendo geralmente a instrumentos sem traços de uso, não contribui para esclarecer esta questão. Tem sido através do registo etnográfico e de uma forte componente de arqueologia experimental que têm surgido alguns indicadores de uso (Masclans Latorre, et. al. 2017), embora ainda muito condicionados à denominação do artefacto - machado - o que pode, à partida, induzir num número restrito de práticas.

Normalmente, aos machados, tem sido atribuída uma função de "corte", associada ao trabalho em madeira (debaste e abate de árvores), distinguindo-se, também aí, das enxós, cujas tarefas, também de corte, podem estar relacionadas com o mato mais rasteiro, ou mesmo de lavra (Le Roux, 1999, p. 150). Alguns estudos funcionais, em contextos neolíticos europeus, têm incidido a sua análise para o trabalho em madeira, quer no abate de árvores, quer no corte de ramos e galhos, na remoção da casca e no aguçar/ afeiçoar de alguns troncos (Lunardi, 2008).

Outra proposta funcional que tem sido, por vezes, apontada é o de trabalho de cava de terrenos agricultados, originando, assim, algumas das marcas de percussões violentas visíveis nos gumes dos machados (e enxós), “....resultantes de impactos dos antigos gumes, de que resultaram lascas de tamanho assinalável (...) em consequência dos choques com pedras dispersas à superfície ou a pequena profundidade." (Cardoso, 1999/2000, p. 242). Ainda relacionada com esta hipótese funcional de instrumentos para sulcar a terra, alguns investigadores sugerem uma possível relação entre estes utensílios e as primeiras fases de produção cerâmica, nomeadamente na extracção de argila do terreno (Crandell, Ionescu e Mirea, 2016, p. 244).

Geralmente, verifica-se neste tipo de utensilagem, a presença de marcas de outras funções, numa utilização multifuncional, que tinha origem no aproveitamento/esgotamento máximo de um utensílio já em desuso, para outros fins. Estas funções $a$ posteriori normalmente resultam em percutores, ou em polidores (na zona do gume) (Gomes, 2002, p. 47). Esta situação não é possível confirmar no exemplar da Moita do Ourives, uma vez que não se conservou o talão (possível zona para a percussão), e o espaço do gume não indicia que tivesse sido usado como polidor.

\section{Martelo}

No decorrer da escavação foi identificado um artefacto em quartzito que levantou algumas dúvidas na sua classificação. A morfologia e a área conservada do instrumento parecem remeter para um talão convexo de um machado ou enxó, fracturado transversalmente, com um corpo picotado e bordos divergentes. Se, primariamente, terá sido parte de alguns destes utensílios, é algo que hoje não podemos avaliar. No entanto, as nítidas marcas de utilização que apresenta numa das extremidades (zona facturada), remete para um instrumento tipo "martelo". De secção circular, conserva um comprimento de $66 \mathrm{~mm}$, por $50 \mathrm{~mm}$ de largura, $44 \mathrm{~mm}$ de espessura e $238 \mathrm{~g}$ de peso (Figura 3, ํㅡㄴ). A sua possível funcionalidade estará associada à actividade de percutir, esmagar ou moer. Na Roménia, ocorrem alguns elementos de tipologia semelhante em contextos neolíticos, tendo sido referida a possibilidade de se constituírem como utensílios que podem ter ajudado a moer elementos minerais que, como elementos não plásticos, integrariam a argila usada na produção de recipientes (Crandell, Ionescu e Mirea, 2016, p. 248).

\section{b) Pedra afeiçoada \\ Moventes}

Na Moita do Ourives recuperaram-se nove moventes, recorrendo a quatro matérias-primas: o granito, o quartzito, o arenito e o quartzo. O seu peso no registo é considerável, podendo assumir um significado determinante na caracterização da tipologia funcional desta ocupação, e na avaliação do subsistema económico praticado pelo grupo.

Os recursos utilizados parecem responder ao substrato geológico imediatamente disponível, figurando quatro exemplares em quartzito, dois em quartzo (conglomerado), um em arenito e um, claramente exógeno na sua composição, em granito.

O conjunto parece corresponder a moventes de pequena dimensão, possivelmente manipulados com uma só mão. Apenas existe um único movente intacto, em arenito, que tem de comprimento $84 \mathrm{~mm}$, de largura $79 \mathrm{~mm}$ e de espessura $44 \mathrm{~mm}$. Apesar de intacto, não corresponderáà peça com maior dimen- 
são, sendo que os restantes exemplares apresentam comprimentos entre os 54 e os $99 \mathrm{~mm}$, larguras entre os 50 e os $88 \mathrm{~mm}$, com as espessuras a oscilarem entre entre os 30 e os $67 \mathrm{~mm}$. São maioritárias as peças com espessuras compreendidas entre os 40 e os $55 \mathrm{~mm}$, com largura entre os 70 e os $79 \mathrm{~mm}$, ocorrendo sete exemplares com um comprimento superior a $80 \mathrm{~mm}$. Nos elementos fragmentados, as fracturas apresentam-se como simples.

Ao nível da sua morfologia, o estado de conformação das peças é pouco variável, apresentando-se estes com forma ovalada ou discóidal (Figura 4).

Os bordos encontram-se, na sua maioria, afeiçoados ou em bruto, sendo que dois não parecem ter sido alvo de uma preparação formal, restando a superfície activa como o único indicador de conformação e utilização enquanto instrumento.

Dos nove moventes, verificou-se em seis a existência de somente uma superfície activa e, em três, a presença de duas superfícies activas, sempre opostas, correspondendo, assim, a um total de 12 superfícies activas. De notar que o exemplar em granito é dos que tem duas superfícies activas, sinal de uso intenso e optimização máxima de um recurso não disponível nas áreas cercanas da ocupação. Observando o estado das superfícies, na tentativa de avaliar a intensidade ou tipo/forma como estes utensílios poderão ter sido utilizados, constata-se que o polimento é o estado mais presente no conjunto da Moita do Ourives, demonstrando, assim, que estes artefactos terão sido alvo de um uso bastante intensivo. Em dois exemplares, só se observa o picotado, ocorrendo em quatro fragmentos, uma combinação de vestígios, entre o picotado e o polido (Tabela 2).

Tal como assinalámos anteriormente, cinco destes exemplares foram identificados em áreas próximas dos dois exemplares de dormentes, não sendo, ainda assim, indiscutível a sua clara associação. Num conjunto com um número razoável de moventes, mas que se caracteriza por um elevado grau de fragmentação, é preciso alguma cautela nas leituras a realizar. É de crer que estes exemplares estejam dispersos, de forma aleatória, pela área intervencionada, sugerindo que correspondam a utensílios abandonados durante a ocupação neolítica e cuja localização, no momento da sua descoberta, poderá não possuir uma relação directa com os espaços onde foram utilizados.

\section{Dormentes}

Nesta categoria, foram identificados dois exemplares, um em quartzo (conglomerado), e um outro em arenito. Uma vez que se trata de um conjunto muito restrito, optou-se por descrever as suas principais características, de forma individualizada.

O exemplar em quartzo é de difícil descrição e classificação. A sua reduzida dimensão devido ao elevado estado de fragmentação levantou dúvidas se se trataria de um dormente ou movente. O facto da área activa se apresentar relativamente polida e, acima de tudo, ligeiramente encovada, levou a que se integrasse nesta classe de utensílios afeiçoados. Foi observada uma única superfície activa, totalmente polida na área conservada, permanecendo as restantes superfícies em estado bruto, assim como os seus bordos. Apresenta um comprimento conservado de $72 \mathrm{~mm}$, por $70 \mathrm{~mm}$ de largura e $55 \mathrm{~m}$ de espessura, com um peso de $338 \mathrm{~g}$.

O outro dormente corresponde a uma peça produzida em arenito que, apesar de ligeiramente fracturada (fractura simples), revela um polimento intenso e de grande amplitude, afectando praticamente a totalidade da superfície funcional, que se encontra visivelmente encovada (Figura 5). Conserva um comprimento de $205 \mathrm{~mm}$, por $214 \mathrm{~mm}$ de largura, $65 \mathrm{~mm}$ de espessura e um peso de $3026 \mathrm{~g}$, apresentado, desta forma, uma dimensão bastante considerável. Apesar de não estar intacto, é possível verificar que, originalmente, apresentaria uma morfologia circular ou subcircular. Apresenta uma única superfície activa, polida, e o bordo intacto está completamente afeiçoado. O grau de polimento da superfície, assim como a sua dimensão, é compatível com acções de moagem baseadas em movimentos horizontais, embora não seja de excluir a possibilidade de ter servido como suporte a acções de trituração por esmagamento, quer de alimentos vegetais, quer de matérias minerais.

A presença destes instrumentos pode atestar a prática, na Moita do Ourives, de actividades económicas próprias das sociedades neolíticas. Trata-se de utensílios que, quando registados em contextos habitacionais, têm sido conotados na bibliografia como indicadores seguros de processamento de alimentos, nomeadamente a moagem e farinação de produtos vegetais (Roux, 1985).

Numa leitura que resulta de uma observação macroscópica, e perante um universo artefactual tão reduzido, e onde um dos exemplares está bastante 
fragmentado, não dispomos, desta forma, de sinais minimamente seguros acerca da sua funcionalidade, e temos consciência que o seu maior contributo é a própria descrição e classificação tipológica destes instrumentos.

Noutro âmbito, seria fundamental proceder a abordagens de foro experimental, mas também recorrer a análises bioquímicas e fitológicas sobre estes elementos. O objectivo seria procurar, nas superfícies trabalhadas, possíveis traços de uso, vestígios microbotânicos e resíduos (como tecido de plantas, fitólitos, resinas e lípidos), tendo consciência que esta ainda é uma prática pouco comum e que acarreta um condicionalismo logístico, uma vez que a realização de exames microscópicos em artefactos pouco móveis, e com alguma dimensão e peso, é um claro obstáculo à sua completa análise (Rowan e Ebeling, 2008).

Por fim, regista-se o facto de nenhum dos elementos se apresentar termoalterado (com sinais de estalamento térmico ou em total desagregação). Não é incomum o seu registo em estruturas ou áreas de combustão, o que leva a questionar se as actividades realizadas com estes elementos se desenvolvem junto ao fogo ou se, numa utilização secundária, integrariam estruturas de combustão. Esta situação não parece verificar-se na Moita do Ourives, mas em outros contextos neolíticos, como no sítio do Prazo, onde os elementos desta natureza surgiram "extremamente termoalterados" e "salvo raras excepções (...) detectaram-se em áreas de combustão", levando o investigador responsável a considerar tais propostas (Monteiro-Rodrigues, 2011, p. 218).

\section{c) Pedra com traços de utilização}

O grupo de utensílios de pedra com traços de utilização é composto por bigorna, percutores e manuporte.

\section{Bigorna}

O único exemplar que se enquadra nesta categoria é sobre um seixo de quartzito apresentando, numa das superfícies, a concavidade e o picotado que resulta da sucessão de impactos num mesmo ponto distinguindo-se, assim, dos restantes artefactos.

Esta bigorna apresenta o suporte em bruto (com excepção da superfície onde se verifica a referida concavidade), sem qualquer bordo polido ou bojardado, estando também ausentes outras marcas/ estigmas de percussão. Trata-se de uma peça, fragmentada, de pequena dimensão, com um compri- mento conservado de $49 \mathrm{~mm}$, larguras de $46 \mathrm{~mm}$, e espessuras de $26 \mathrm{~mm}$.

Este tipo de utensílio está normalmente associado ao talhe bipolar (Diniz, 2007, p.10o e 111; Monteiro-Rodrigues, 2011, p. 185), sendo esta uma prática atestada nesta ocupação (Neves, 2018).

\section{Percutores}

Neste ponto, menciona-se unicamente os artefactos que apresentam estigmas de percussão em áreas que não foram alvo de debitagem ou que denunciam qualquer actividade prévia. Desta forma, estes exemplares distinguem-se dos possíveis percutores em quartzito identificados na Moita do Ourives e que terão sido inicialmente núcleos para a produção de lascas (Neves, 2018).

O universo de percutores corresponde a seis exemplares, todos sobre seixo de quartzito. Trata-se de percutores duros utilizados, com probabilidade, no talhe através da percussão directa sobre núcleos de quartzito e quartzo, sendo esta uma técnica claramente documentada nos materiais de pedra lascada da Moita do Ourives.

Dos seis percutores, três estão intactos e três encontram-se fracturados. Em um dos casos, é visível que a zona de percussão terá ficado inactiva em sequência do levantamento de uma lasca pela própria percussão. Num outro caso, a fractura terá resultado de acção térmica, uma vez que este percutor terá sido, como função secundária, um termoclasto.

Quanto aos bordos, em três percutores encontram-se bojardados, permanecendo os restantes em estado bruto. Os estigmas de percussão que permitiram a sua classificação tipológica encontram-se concentrados e as superfícies activas identificadas estão percutidas. De registar que os únicos três casos onde só se verificou uma superfície activa correspondem aos três exemplares fracturados. Nos restantes, um percutor possui três superfícies com traços de utilização, e dois com duas superfícies activas. As superfícies não activas permanecem sempre em estado bruto.

Relativamente às suas dimensões, trata-se de peças de pequena e média dimensão, com comprimentos compreendidos entre os 31 e $84 \mathrm{~mm}$, larguras entre os 30 e os $75 \mathrm{~mm}$, e espessuras que variam entre os 19 e os 6 omm, sendo o peso máximo aferido de $478 \mathrm{~g}$ (Figura 6). 


\section{Manuporte}

Corresponde a um único elemento em granito, matéria-prima que não se insere no ambiente geológico da Moita do Ourives. Trata-se de um pequeno fragmento com os bordos e superfícies, conservadas, em bruto. Foi classificada como uma "lasca em bruto", sendo impossível aferir qualquer relação com um processo técnico específico.

\section{DISCUSSÃO: O QUE PODE REVELAR O CONJUNTO DE PEDRA POLIDA E AFEIÇOADA DA MOITA DO OURIVES?}

\subsection{Matéria-prima: aquisição e seus territórios}

Ao nível da aquisição de matérias-primas, constata-se alguma diversidade nas estratégias adoptadas por estas comunidades a partir do final do $5^{\circ}$ e ao longo do $4^{\circ}$ milénio. Se, por um lado, existe uma clara tendência pela opção mais conservadora - utilização preferencial pelos recursos essencialmente disponíveis - a verdade é que o registo arqueológico mostra a presença de alguns elementos artefactuais, cuja matéria-prima deverá ter sido obtida em espaços localizados a média/longa distância face ao contexto onde foram recolhidos.

$\mathrm{Na}$ Moita do Ourives, na selecção da matéria-prima para a produção de líticos, a opção recaiu sobre os recursos locais, visível nas elevadas percentagens de quartzito e quartzo no conjunto.

No entanto, e à imagem do verificado na pedra lascada onde ocorre uma percentagem de elementos de origem exógena (sílex e jaspe) que coloca as estratégias de exploração do espaço e aquisição de recursos em áreas que distam entre $\sim 30$ a $100 \mathrm{Km}$ para Norte, Oeste e Sul do sítio (Matias e Neves, 2017), verifica-se que, também, na produção de uma pequena parte dos artefactos de pedra polida/ afeiçoada a comunidade ultrapassou as imediatas proximidades da área de ocupação, na procura da matéria-prima que melhor se enquadrava, funcional, simbólica e esteticamente, no artefacto que queria produzir.

Para o granito e rocha anfibólica utilizadas nesta ocupação, as observações de proveniência detectam territórios de aquisição, revelando presumíveis trajectórias de circulação num espaço igualmente amplo (Figura 7).

Estes prováveis espaços de exploração apresentam testemunhos de ocupação humana dentro do período reconhecido para o Neolítico médio (c. 4500 -
-3200 cal BC), dando coerência científica e empírica a esta leitura. Independentemente do seu enquadramento cronológico específico inserido neste período (algumas ocupações corresponderão ao Neolítico médio inicial e, outras, a uma fase mais plena, mais próxima do horizonte crono-cultural da Moita do Ourives), o que importa assinalar é que as áreas de aquisição das matérias-primas exógenas identificadas na pedra polida e afeiçoada da Moita do Ourives foram, efectivamente, cenários de acção das populações do Neolítico médio, apresentando-se tanto como lugares de Vida como de Morte (Neves, 2018). As fontes primárias de granito e anfibolito, situadas nos afloramentos do Maciço Hespérico, mais próximas da ocupação em análise, encontram-se na área do interior alentejano, entre $\sim 40$ a $50 \mathrm{~km}$ de distância. Neste espaço, localizado na região de Vendas Novas - Montemor-o-Novo, surgem testemunhos de ocupações desde o final do Neolítico antigo (ex.: Patalim), mas essencialmente, espaços funerários com utilizações no Neolítico médio, como a Gruta do Escoural ou o sepulcro megalítico do Cabeço da Areia (Ferreira, 2005; Araújo e Lejeune, 1995; Rocha, 2005). Relativamente próximo destes locais, ligeiramente mais para Sudeste, já na região de Évora, estão atestadas ocupações de cariz residencial da fase mais inicial do Neolítico médio, em Hortinha 1, Vale Rodrigo 2 e Vale Rodrigo 3 (Rocha, 2007; Armbruester, 2006 e 2008; Larsson, 2000).

A cerca de $60 \mathrm{~km}$ de distância da Moita do Ourives, e das outras ocupações do Neolítico médio do Baixo Tejo onde foram identificados elementos em anfibolito e granito, como o Monte da Foz (Neves, 2011), na área de Montargil, Ponte de Sor e Mora, ocorrem formações geológicas que podem ter sido fontes primárias destas matérias-primas. Aqui, além dos habitats de uma fase de transição entre o Neolítico antigo e Neolítico médio do Alminho 1 e Bernardo 1, na região de Ponte Sor (Deus, 2008b), a passagem das comunidades do Neolítico médio no território está atestada na área de Mora, através da utilização funerária do sepulcro megalítico da Cabeceira 4, datado entre do $2^{\circ}$ e $3^{\circ}$ quartel do $4^{\circ}$ milénio cal BC (Carvalho e Rocha, 2016).

A uma distância ligeiramente superior, mas ainda como área de possível proveniência de anfibolito, situa-se a zona do médio Tejo, a 80-9okm da Moita do Ourives. Aqui, a presença de testemunhos associados ao Neolítico médio carece de alguma confirmação, apesar da presença de um significativo con- 
junto de monumentos megalíticos de cariz funerário com possível ocupação associada a este momento crono-cultural (Cruz, 1996; Burbidge et al, 2019). Já no espaço mais próximo de Tomar e Vale do Nabão, encontram-se as ocupações funerárias do Neolítico médio nas grutas do Caldeirão, Cadaval e Ossos, inseridas, genericamente, nos primeiros três quartéis do $4^{\circ}$ milénio cal BC (Zilhão, 1992; Lopes, 2005/2006; Oosterbeek, 1995).

As áreas de proveniência localizadas no Alentejo interior e do Médio Tejo, origem provável dos artefactos de pedra polida e afeiçoada da Moita do Ourives são, igualmente, os locais de aprovisionamento de matérias-primas para um conjunto de outros sítios com ocupações do Neolítico médio.

Neste particular, destacam-se os machados identificados entre os espólios votivos da gruta do Algar do Bom Santo, Lugar do Canto e Porto Covo, que apontam para fontes de aquisição idênticas, localizadas nas formações do Complexo Precâmbrico da área de Abrantes-Tomar e Montemor-o-Novo (Cardoso e Carvalho, 2008, p. 274; Cardoso, 2014, p. 190).

Tal como se verifica para a Moita do Ourives, a ocorrência de artefactos nestes contextos em particular, cuja matéria-prima poderá ter sido obtida a grande-distância, reflecte acções de índole económica, suportadas por uma complexidade social bem vincada. Por aferir, estará o estado em que estes produtos chegam ao seu destino, se em bruto, pré-formatados, ou já como produto final, numa leitura, por ora, impossível de definir.

Observando os locais de origem das matérias-primas/artefactos em pedra polida e afeiçoada da Moita do Ourives, constata-se que são áreas cujo acesso terá sido facilitado pelos recursos fluviais como o Sorraia e Almansor, muito próximos do sítio arqueológico que, no momento da sua ocupação durante o Neolítico médio, apresentavam um caudal ainda fortemente marcado pela transgressão flandriana (Vis, 2009).

O curso destas ribeiras coincide com pontos de "chegada a", ou "partida de" estes lugares, tanto a montante (região de Montargil, Ponte de Sor, Mora e Pavia no caso do Sorraia; região de Montemor-o-Novo e Vendas Novas, no caso do Almansor), como a jusante (na margem esquerda do Tejo, perto de Benavente, onde se localizam a Moita do Ourives e, também, o Monte da Foz 1 o sítio do Neolítico médio inicial do Monte da Foz 1 - Neves, 2011), tendo tido um papel determinante na circulação das matérias-primas, produtos, ideias e, acima de tudo, pessoas e animais.

\subsection{Subsistema económico do Neolítico} médio: os dados da pedra polida e afeiçoada

Perante a parca informação directa sobre as práticas económicas, a reconstituição do subsistema económico procura utilizar a cultura material como elemento de diagnóstico, destacando-se a presença de instrumentos de pedra polida e afeiçoada (machados, enxós, moventes e dormentes), como indicadores indirectos da presença e maior/menor peso das práticas agrícolas.

Se tomarmos, unicamente, em atenção a frequência destes elementos no registo de contextos habitacionais, então o peso das práticas agrícolas no centro e sul de Portugal é reduzido, numa leitura que já se verificava numa fase final do Neolítico antigo evolucionado (finais do $6^{\circ}$ e primeira metade do $5^{\circ}$ milénio cal BC) (Tabela 3).

Na pedra polida, a presença de machados e enxós é mesmo residual, sendo que nos contextos onde essa informação surge contabilizada, o número de cada um destes elementos não supera as duas unidades. O estado de fragmentação de muitos dos vestígios com sinais de polimento, dificulta a sua caracterização ao mesmo tempo que permite aumentar o número de ocorrências, o que pode induzir em erros de avaliação. Neste particular, a constante presença de pequenas "lascas de anfibolito" (ex.: Monte da Foz, Cerradinho do Ginete e Pena d'Água), não pode assumir, na leitura destes sítios, um peso semelhante a um instrumento inteiro ou parcialmente fracturado. De igual modo, surgem alguns contextos onde, além da ausência de contabilização exacta do número de artefactos desta natureza, não se apresenta qualquer informação quanto à sua caracterização e contexto de proveniência, o que limita a reflexão acerca destes elementos.

Quanto à pedra afeiçoada, o registo arqueográfico parece revelar uma presença/recurso maior a este tipo de instrumentos, nomeadamente os elementos de moagem (dormentes e moventes), surgindo ainda fragmentos de polidores ou de outros instrumentos por identificar, devido às reduzidas dimensões que apresentam. A ausência de informação detalhada acerca da contabilidade e descrição tipológica dos vestígios, limita qualquer interpretação. Por outro lado, a possibilidade de corresponderem a artefactos relacionados com práticas de moagem de recur- 
sos silvestres diminui o seu valor como indicador de práticas agrícolas. Para já, sem análises bioquímicas e fitológicas sobre as superfícies activas, na procura de traços de uso e vestígios microbotânicos, esta será uma questão deixada em aberto.

De notar que a maior presença de instrumentos em pedra polida e afeiçoada parece associada a contextos residenciais com ocupações mais permanentes como Castelo Belinho, Palmeirinha, Salema e Fábrica de Celulose.

A generalizada baixa presença de artefactos de pedra polida e afeiçoada nos espaços domésticos poderá estar, igualmente, relacionada com a realização das práticas agrícolas em áreas exteriores às ocupações, constituindo-se como espaços de grande invisibilidade arqueológica estando, na sua maioria, por identificar. No entanto, os valores disponíveis terão de ser levados em conta na reconstituição do subsistema económico, podendo constituir-se como indiciadores do peso que as práticas produtivas teriam neste momento.

\section{CONCLUSÃO}

Em contraste com os restantes elementos que integram o clássico "pacote neolítico", os utensílios em pedra polida e afeiçoada apresentam-se nos contextos neolíticos, do Ocidente peninsular, em percentagens muito residuais totalmente ausentes do registo. Em conjunto com esta evidência, a presença de elementos afeiçoados ainda em contextos do Mesolítico final, como no Prazo (Monteiro-Rodrigues, 2011, p. 223), deverá levar a uma reflexão acerca da importância e real funcionalidade destes instrumentos, se estes estão, exclusivamente relacionados com práticas agrícolas e se constituem um testemunho efectivo da intervenção de uma comunidade no meio natural onde habita, conseguindo mesmo alterar o ecossistema que explora e do qual depende.

No território actualmente português, as práticas agrícolas estão atestadas desde as fases iniciais do processo de Neolitização (Lopéz-Dóriga e Simões, 2015), mas, ao contrário dos recipientes cerâmicos que surgem em percentagens significativas desde os momentos iniciais do Neolítico, os artefactos de pedra polida e afeiçoada só parecem tornar-se mais frequentes, em contextos habitacionais, já na fase final desta etapa crono-cultural.

Nos estudos da pedra afeiçoada, para a qual não existe uma tipologia de referência nem uma padroniza- ção da sua nomenclatura e metodologias de análise, verifica-se ainda uma linguagem descritiva dominada por preferências individuais, com diferentes autores a utilizar termos distintos para descrever instrumentos semelhantes e onde a funcionalidade proposta está muito dependente da com a morfologia do artefacto (Rowan e Ebeling, 2008).

Por fim, é preciso ter em conta que se trata de elementos artefactuais que, pela sua durabilidade e resistência, possuíram muitas vezes um carácter multifuncional, sendo difícil de distinguir qual o seu uso primário e secundário dificultando, adicionalmente, a avaliação do contexto físico do seu uso e abandono.

A base empírica é, assim, escassa e parcelar, pois em alguns contextos a contabilidade destes elementos não se encontra disponível, nem mesmo a sua devida descrição e caracterização tipológica.

No quotidiano de um grupo do Neolítico antigo e médio, os dados hoje disponíveis são, ainda, pouco conclusivos acerca das práticas a que os elementos de pedra afeiçoada e polida estariam relacionados, assim como na definição do seu real peso no subsistema económico nomeadamente no quadro das práticas produtivas, numa reflexão que importa retomar no futuro.

\section{BIBLIOGRAFIA}

Atlas do Ambiente. Portugal. Carta Litológica. 1 / 1000 ooo (material cartográfico). Lisboa: Instituto Hidrográfico. Comissão Nacional do Ambiente. Secretaria de Estado do Ambiente. 1982. Folha I.13.

ARAÚJO, Ana Cristina \& LEJEUNE, Marylise (1995) - Gruta do Escoural: necrópole neolítica e arte rupestre paleolítica. Lisboa: Instituto Português do Património Arquitectónico e Arqueológico (Trabalhos de Arqueologia; 8).

ARMBRUESTER, Tanya (2006) - Before the monument? Ceramics with a line below the rim (A preliminary report from Vale de Rodrigo 3, Évora). Simbolismo, arte e espaços sagrados na Pré-História da Península Ibérica: actas do $4 .^{\text {. }}$ Congresso de Arqueologia Peninsular. Faro: Universidade do Algarve, pp. 53-67.

ARMBRUESTER, Tanya (2008) - Technology neglected? A painted ceramic fragment from the dated Middle Neolithic site of Vale Rodrigo 3. Vipasca. Aljustrel. 2. aㅗ série. 2, pp. 83-94.

BURBIDGE, Chris; CARDOSO, Guilherme; DIAS, Isabel; OOSTERBEEK, Luiz; PRUDÊNCIO, Isabel; SCARRE, Chris (2019) - Luminescence dating at the Anta da Lajinha, In SCARRE, C. \& OOSTERBEEK, L. (eds.), Megalithic 
Tombs in Western Iberia: Excavations at the Anta da Lajinha, Oxbow Books, Oxford, pp. 68-73.

CARDOSO, João Luís (1999/200o) - Os artefactos de pedra polida do povoado pré-histórico de Leceia (Oeiras). Estudos Arqueológicos de Oeiras. Oeiras. 8, pp. 241-323.

CARDOSO, João Luís (2014) - Polished stone tools. In CARVALHO, A. F. (ed.), Bom Santo Cave (Lisbon) and the Middle Neolithic Societies of Southern Portugal. Faro: Universidade do Algarve (Promontoria Monográfica; 17), pp. 185-194.

CARDOSO, João Luís \& CARVALHO, António Faustino (2008) - A Gruta do Lugar do Canto (Alcanede) e a sua importância no faseamento do Neolítico no território português. In CARDOSO, João L. (ed.), Homenagem a Octávio da Veiga Ferreira. Oeiras: Câmara Municipal de Oeiras, pp. 269-30o (Estudos Arqueológicos de Oeiras, 16).

Carta Geológica de Portugal: 1/500.00o (material cartográfico). Lisboa: Serviços Geológicos de Portugal. 1992.

CARVALHO, António Faustino (1998) - Abrigo da Pena d' Água (Rexaldia, Torres Novas): resultados das campanhas de sondagem (1992-1997). Revista Portuguesa de Arqueologia. Lisboa. 1:2, pp. 39-72.

CARVALHO, António Faustino (2008) - A Neolitização do Portugal Meridional: os exemplos do Maciço Calcário Estremenho e do Algarve Ocidental. Promontória Monográfica, 12. Universidade do Algarve, Faro.

CARVALHO, António Faustino \& ROCHA, Leonor (2016) - Datação directa e análise de paleodietas dos indivíduos da anta de Cabeceira 4. ․ㅡ (Mora, Portugal). digitAR, nº .3 , Imprensa da Universidade de Coimbra, pp. 53-61.

CARVALHO, António Faustino \& STRAUS, Lawrence G. (2013) - New Radiocarbon dates for Algarão da Goldra (Faro, Portugal): a contribution to the Neolithic of the Algarve. In JIMÉNEZ ÁVILA, J.; BUSTAMANTE ÁlVAREZ, M. \& GARCÍA CABEZAS, M. (eds.) - VI Encuentro de Arqueología del Suroeste Peninsular, IAM, pp. 193-205. Edição electrónica.

COONEY, Gabriel \& MANDAL, Stephen (1998) - The irish stone axe project. Monograph 1 . Wicklow: Wordwell, Ltd. 229 p.

CRANDELL, Otis; IONESCU, Corina; MIREA, Pavel (2016) - Neolithic and Chalcolithic stone tools used in ceramics production: Examples from the south of Romania. Journal of Lithic Studies, vol. 3, 1, University of Edinburgh, pp. 241-258.

CRUZ, Ana Rosa (1996) - Vale do Nabão: Do Neolítico à Idade do Bronze. Braga: Universidade do Minho.

DEUS, Manuela (2008a) - Alminho 1/Álamo - Montargil, Ponte de Sor. Relatório dos trabalhos arqueológicos efectuados em 2008. Instituto Português de Arqueologia, Lisboa (Policopiado).

DEUS, Manuela (2008b) - O Neolítico antigo do baixo curso do rio Sor: os sítios Bernardo 1 e Alminho 1 (Montargil, Ponte de Sor). Promontória, Ano 6, Número 6, pp. 95-114.
DINIZ, Mariana (2007) - O Sítio da Valada do Mato (Évora): aspectos da neolitização no Interior/Sul de Portugal. Lisboa: Instituto Português de Arqueologia. (Trabalhos de Arqueologia; 48).

FERREIRA, Ângela (2005) - O sítio do Patalim (Montemor-o-Novo) no seu contexto Neolítico. Dissertação de Mestrado em Pré-história e Arqueologia. Lisboa, FLUL. Policopiado.

GOMES, Isidro M. T. (2002) - Estudo do Material Lítico do Crasto de Palheiros (Murça). Uma Primeira Abordagem Metodológica $-2^{\underline{a}}$ Parte, Portugália, Nova Série, XXIII, Porto, F.L.U.P., pp. 35-115.

GOMES, Mário Varela (2010) - Castelo Belinho (Algarve): A ritualização funerária em meados do V milénio AC. GIBAJA, J. F. \& CARVALHO, A. F. (eds.) Os Últimos Caçadores-Recolectores e as Primeiras Comunidades Produtoras do Sul da Península Ibérica e do Norte de Marrocos, Faro, Universidade do Algarve, pp. 69-8o.

GONÇALVES, Victor S. (1989) - Megalitismo e Metalurgia no Alto Algarve Oriental, uma aproximação integrada. Lisboa: INIC/UNIARQ. (2 volumes).

LARSSON, Lars (2000) - Symbols in stone: ritual activities and petrified traditions. Actas do $3 .{ }^{\circ}$ Congresso de Arqueologia Peninsular, UTAD, Vila Real, Setembro de 1999. Porto: ADECAP, vol. 3, pp. 445-458.

LE ROUX, Charles-Tanguy. (1999) - L'outillage de pierre polie enméta-dolérite du type A. Les ateliers de Plussulien (Côtesd'Armor): Production et diffusion au Néolithique dansla France de l'ouest et au-delà. Travaux du Laboratoire "Anthropologie, Préhistoire et Quaternaire Armoricains", 43, UMR 6566 "Civilisations atlantiques etArchéosciences”, Université de Rennes I.

LOPES, Ś́lvia C. (2005-2006) - Paleobiologia da gruta-necrópole do Cadaval (Tomar): Contribuição para o estudo da Neolitização no Alto Ribatejo. Master Erasmus Mundus em Quaternário e Pré-História. Tomar: Instituto Politécnico de Tomar. Policopiado.

LÓPEZDÓRIGA, Inês \& SIMÕES, Teresa (2015) - Los cultivos del Neolítico Antiguo de Sintra: Lapiás das Lameiras 98 y São Pedro de Canaferrim: resultados preliminares. In GONÇALVES, V.S.; DINIZ, M.; SOUSA, A. C., (eds.) 5.․ำ Congresso do Neolítico Peninsular. Actas. Lisboa: UNIARQ. pp. 98-107.

LUNARDI, Anna (2008) - Experimental testing with polished green stone axes and adzes: technology and use. In LONGO, Laura e SKAKUN, Natalia (eds.) "Prehistoric Technology" 40 years later. Functional Studies and the Russian Legacy. Proceedings of the International Congress Verona (Italy) 20-23 April 2005, pp. 369-373.

MASCLANS LATORRE, Alba; PALOMO PÉREZ, Antoni; GIBAJA BAO, Juan F.; REMOLINS ZAMORA, Gerard \& GÓMEZ-GRAS, David (2016) - Use-wear analysis of Neolithic polished axes and adzes: The site of "Bòbila Madurell- 
Can Gambús-1-2” (Northeast Iberian Peninsula). Quaternary International, Elsevier, pp. 1-17.

MATIAS, Henrique \& NEVES, César (2017) - A gestão do sílex durante o Neolítico médio da Moita do Ourives (Benavente, Portugal). ARNAUD, J. M. \& MARTINS, A. (coords.) Arqueologia em Portugal: 2017 - Estado da Questão, Lisboa, Associação dos Arqueólogos Portugueses, pp. 489-504.

MONTEIRO-RODRIGUES, Sérgio (2011) - Pensar o Neolítico Antigo. Estudos Pré-Históricos. Centro de Estudos Pré-Históricos da Beira Alta, XVI, Viseu.

NEVES, César (2010) - Monte da Foz 1 (Benavente): um episódio da Neolitização na margem esquerda do Baixo Tejo. Dissertação de Mestrado em Arqueologia apresentada à Faculdade de Letras da Universidade de Lisboa. 2 Vols. (policopiado).

NEVES, César (2018) - O Neolítico médio no Ocidente Peninsular: o sítio da Moita do Ourives (Benavente), no quadro do povoamento do $5^{\circ}$ e $4^{\circ}$ milénio AC. Dissertação de Doutoramento apresentada à Faculdade de Letras da Universidade de Lisboa. 2 Vols. (policopiado).

NEVES, César \& DINIZ, Mariana (2014) - Acerca dos cenários da acção: estratégias de implantação e exploração do espaço nos finais do $5^{\circ}$ e na primeira metade do $4^{\circ}$ milénio AC, no Sul de Portugal. Estudos do Quaternário, 11, APEQ, Braga, pp. 45-58.

NEVES, César; RODRIGUES, Ana Filipa; DINIZ, Mariana (2008) - Moita do Ourives - um sítio do Neolítico médio no Baixo Tejo (Benavente, Portugal): matérias-primas e cultura material. HERNÁNDEZ PEREZ, M.; SOLER DÍAZ, J.; LÓPEZ PADILLA, J. (eds.) IV Congreso del Neolítico Peninsular. Alicante: MARQ. 2, pp. 216-221.

NUNES, André \& CARVALHO, António Faustino (2013) - O Neolítico Médio no Maciço Calcário Estremenho: estado actual dos conhecimentos e perspectivas de investigação futura, In ARNAUD, J. M.; MARTINS, A.; NEVES, C. (coords.), Arqueologia em Portugal - 150 anos, Lisboa: Associação dos Arqueólogos Portugueses, pp. 329-334.

OOSTERBEEK, Luiz (1995) - O Neolítico e o Calcolítico na região do Vale do Nabão (Tomar). In KUNST, M. (coord.) Origens, estruturas e relações das Culturas calcolíticas da Península Ibérica: Actas das I Jornadas Arqueológicas de Torres Vedras, 3-5 Abril 1987. Lisboa: IPPAR, pp. 101-111. (Trabalhos de Arqueologia, 7).

READ, Caroline; GRAPES, Rodney; LILLIOS, Katina (1997) - Petrography and Chemical Analyses of Prehistoric Amphibolite Artefacts from Portugal and Possible Source Rocks from Western Iberia. Analytical Facility Publications, 19. Victoria University of Wellington. Wellington, New Zealand, pp. 1-19.

ROCHA, Leonor (2005) - Estudo do megalitismo funerário no Alentejo Central: a contribuição de Manuel Heleno. Dissertação de Doutoramento apresentada à Faculdade de Letras da Universidade de Lisboa, policopiado.
ROCHA, Leonor (2007) - Relatório de escavação do sítio arqueológico da Hortinha 1 (Torre de Coelheiros, Évora).

RODRIGUES, Ana Filipa (2006) - Moita do Ourives: um habitat do Neolítico médio do Baixo Tejo. Do Epipaleolítico ao Calcolítico na Península Ibérica. Actas do IV Congresso de Arqueologia Peninsular. Faro: Universidade do Algarve. pp. 249-262. (Promontoria Monográfica; 04).

ROUX, Valentine (1985) - Le matériel de broyage, Paris, Éditions Recherche sur les Civilizations, Mémoire nํㅜㄷ․

ROWAN, Yorke M. \& EBELING, Jennie (2008) - Introduction: The Potential of Ground Stone Studies. In ROWAN, Y. M. \& EBELING, J. R. (eds.), New approaches to old stones. Recent Studies of Ground Stone Artifacts. (Approaches to Anthropological Archaeology).

SILVA, Carlos Tavares da \& SOARES, Joaquina (2004) - Intervenção arqueológica no sítio neolítico do Brejo Redondo (Sines). Musa, museus, arqueologia e outros patrimónios, Fórum Intermuseus do Distrito de Setúbal, pp. 83-105.

SILVA, Carlos Tavares da \& SOARES, Joaquina (2018) Para o estudo do Neolítico Médio: o sítio da Fábrica de Celulose (Mourão). Revista Portuguesa de Arqueologia, DGPC, Lisboa, 21, pp. 5-23.

SILVA, Carlos Tavares da; SOARES, Joaquina; COELHO-SOARES, Antónia (2010) - Arqueologia de Chãos de Sines. Novos elementos sobre o povoamento Pré-histórico. Actas do $2^{\circ}$ encontro de História do Alentejo Litoral, Sines, Centro Cultural Emmérico Nunes, pp. 11-34.

SIMÕES Carlos Duarte, REBELO, Paulo, NETO, Nuno \& CARDOSO, João Luís (2020) - Lisboa no Neolítico antigo: resultados das escavações no Palácio Ludovice. Estudos Arqueológicos de Oeiras, 26, Oeiras, Câmara Municipal, 2020, pp. 11-40.

SOARES, Joaquina \& SILVA, Carlos Tavares da (1980) O neolítico antigo na área de Sines. Descobertas Arqueológicas no Sul de Portugal. Centro de História da Universidade de Lisboa e Museu de Arqueologia e Etnografia da Assembleia Distrital de Setúbal, pp. 5-12.

SOARES, Joaquina \& SILVA, Carlos Tavares da (1992) Para o conhecimento dos povoados de megalitismo de Reguengos. Setúbal Arqueológica. Setúbal. IX-X, pp. 37-88.

SOARES, Joaquina \& SILVA, Carlos Tavares da (2013) Economia agro-marítima na Pré-História do estuário do Sado. Novos dados sobre o Neolítico da Comporta. Pré-história das Zonas Húmidas. Paisagens de Sal. SOARES, Joaquina (ed.), Setúbal Arqueológica, 14, MAEDS, Setúbal, pp. 145-170.

STRAUS, Lawrence G.; ALTUNA, J.; FORD, D.; MARAMBAT, L.; RHINE, J. S.; SCHWARCZ, J.-H. P.; VERNET, J.-L. (1992) - Early farming in the Algarve (Southern Portugal): A preliminary view from two cave excavations near Faro. Trabalhos de Antropologia e Etnologia, Porto, 32, pp.141-161. 
URIBE, Marta Díaz-Guardamino (2004) - As lareiras infratumulares, MORAN, E. \& PARREIRA, R. (coord.) Alcalar 7 . Estudo e reabilitação de um monumento megalítico. Cadernos, 6, Lisboa: Instituto Português do Património Arquitectónico, pp. 137-147.

VALERA, António (2006) - O Neolítico da desembocadura do Paleo Estuário do Tejo: dados preliminares do Palácio dos Lumiares (Bairro Alto, Lisboa). Era - Arqueologia, Revista de divulgação científica de estudos arqueológicos, Dafundo: Era-Arqueologia S.A.7, pp. 86-108.

VIS, Geert-Jan (2009) - Fluvial and marine sedimentation at a passive continental margin. The late Quaternary Tagus deposicional system. Ph.D. dissertation. VU University Amsterdam, 244 p.
VIS, Geert-Jan; KASSE, Cornelis; VANDENBERGHE, Jef (2008) - Late Pleistocene and Holocene palaeogeography of the Lower Tagus Valley (Portugal): effects of relative sea level, valley morphology and sediment supply. Quaternary Science Reviews. 27, pp. 1682-1709.

ZILHÃO, João (1992) - Gruta do Caldeirão. O Neolítico Antigo. Lisboa: Instituto Português do Património Arquitectónico e Arqueológico. (Trabalhos de Arqueologia; 6).

\begin{tabular}{|l|l|l|l|l|l|l|l|}
\hline \multicolumn{2}{|l}{ Utensilagem } & Anfibolito & Granito & Arenito & Quartzito & Quartzo $\begin{array}{l}\text { Total } \\
(N-\text { e } \%)\end{array}$ \\
\hline \multirow{2}{*}{ Pedra polida } & Machado & 1 & - & - & - & - & $1-4,8 \%$ \\
\cline { 2 - 9 } & Martelo & - & - & - & 1 & - & $1-4,8 \%$ \\
\hline \multirow{2}{*}{ Pedra afeiçoada } & Movente & - & 1 & 2 & 4 & 2 & $9-42,8 \%$ \\
\cline { 2 - 9 } & Dormente & - & - & 1 & - & 1 & $2-9,5 \%$ \\
\hline $\begin{array}{l}\text { Pedra com traços } \\
\text { de utilização }\end{array}$ & Bigorna & - & - & - & 1 & - & $1-4,8 \%$ \\
\hline & Percutor & - & - & - & 6 & - & $6-28,5 \%$ \\
\hline Manuportes & Lasca em bruto & - & 1 & - & - & - & $1-4,8 \%$ \\
\hline Total (Noe $\%)$ & & $1-4,8 \%$ & $2-9,5 \%$ & $3-14,3 \%$ & $12-57,1 \%$ & $3-14,3 \%$ & $21-100 \%$ \\
\hline
\end{tabular}

Tabela 1-Pedra polida, afeiçoada e com traços de utilização - Inventário geral.

\begin{tabular}{|l|l|}
\hline Estado & Total \\
\hline Picotadas & $2-16,6 \%$ \\
\hline Picotadas e polidas & $4-33,3 \%$ \\
\hline Polidas & $6-50 \%$ \\
\hline Total & $\mathbf{1 2 - 1 0 0 \%}$ \\
\hline
\end{tabular}

Tabela 2-Moventes - estado das superfícies. 


\begin{tabular}{|c|c|c|c|c|c|c|c|}
\hline \multirow[b]{2}{*}{ Sítio } & \multicolumn{3}{|c|}{ Pedra polida } & \multicolumn{3}{|c|}{ Pedra afeiçoada } & \multirow[b]{2}{*}{ Ref. Bibliográfica } \\
\hline & Machado & Enxó & $\begin{array}{c}\text { Outro / } \\
\text { Indeterminado }\end{array}$ & Dormente & Movente & $\begin{array}{c}\text { Outro / } \\
\text { Indeterminado }\end{array}$ & \\
\hline \multicolumn{8}{|l|}{ Neolítico antigo evolucionado } \\
\hline Alcalar 7 (ocup. prévia) & - & - & - & 13 & - & - & Uribe, 2004 \\
\hline Patalim & 1 & - & - & 1 & 9 & - & Ferreira, 2005 \\
\hline Salema & - & $\nabla$ & $\nabla$ & \multicolumn{2}{|c|}{$\mathrm{X}$} & - & Soares e Silva, 1980 \\
\hline CPM III & - & - & - & - & $1+1$ & - & Carvalho, 20o8a \\
\hline Laranjal Cabeço das Pias & \multicolumn{2}{|l|}{$1^{*}$} & - & - & - & - & Carvalho, 2008a \\
\hline Pena d’Água(Ea) & - & - & - & - & 1 & - & Carvalho, 2008a \\
\hline Pena d’Água (Eb-topo) & - & - & - & - & - & - & Carvalho, 20o8a \\
\hline Palácio Ludovice & $\nabla$ & $\nabla$ & 2 & 1 & - & - & Simões, et al. 2020 \\
\hline \multicolumn{8}{|l|}{ Neolítico médio inicial } \\
\hline Algarão da Goldra & - & - & - & 2 & 2 & - & $\begin{array}{l}\text { Straus, et al., } 1992 \\
\text { Carvalho e Straus, } 2013\end{array}$ \\
\hline Castelo Belinho & $\nabla$ & $\nabla$ & - & $\nabla$ & $\nabla$ & 1 & Gomes, 2010, p.70 \\
\hline Palmeirinha & 2 & 2 & - & 1 & - & - & Silva et al., 2010 \\
\hline Brejo Redondo & - & 1 & 4 & 3 & - & 5 & $\begin{array}{l}\text { Silva e Soares 2004; } \\
\text { Silva et ai, } 2010\end{array}$ \\
\hline Pontal & - & - & - & - & - & - & Soares e Silva, 2013 \\
\hline Vale Rodrigo 2 (ocup. prévia) & - & - & - & - & - & - & Armbruester, 2006 \\
\hline Vale Rodrigo 3 (ocup. prévia) & - & - & - & - & - & - & Armbruester, 2008 \\
\hline Hortinha I (ocup. prévia) & 1 & - & - & - & - & - & Rocha, 2007 \\
\hline Fábrica da Celulose & 1 & - & 4 & 6 & 3 & 7 & Silva e Soares, 2018; \\
\hline Pipas & - & - & - & 2 & - & 1 & $\begin{array}{l}\text { Soares e Silva, 1992; } \\
\text { info. oral }\end{array}$ \\
\hline Bernardo 1 & - & - & - & - & - & - & Deus, $2008 \mathrm{a}$ \\
\hline Alminho 1 & - & - & - & 1 & 1 & - & Deus, 2008a \\
\hline Monte da Foz I & - & - & 1 & - & - & 3 & Neves, 2010 \\
\hline Palácio Lumiares & - & - & - & - & - & 1 & Valera, 2006 \\
\hline Pena d'Água(Db) & - & - & 2 & - & - & - & Carvalho, 1998 \\
\hline Cerradinho do Ginete & 1 & - & 2 & - & - & - & Nunes e Carvalho, 2013 \\
\hline \multicolumn{8}{|l|}{ Neolítico médio pleno } \\
\hline Barrosinha & - & - & - & $\nabla$ & - & $\nabla$ & Soares e Silva, 2013 \\
\hline Moita do Ourives & 1 & - & - & 2 & 9 & - & Neves (2018) \\
\hline Pena d’Água (Da) & - & - & 2 & - & - & - & Carvalho, 1998 \\
\hline
\end{tabular}

Tabela 3 - Artefactos de Pedra Polida e/ou Afeiçoada em contextos domésticos do final do Neolítico antigo / Neolítico médio no Sudoeste Peninsular.

Legenda:

$\square$ - Indicação da presença mas sem especificar a quantidade;

$\mathrm{X}$ - Autores revelam a presença de "elementos de mós manuais”, sem especificar a sua tipologia e quantificação;

* Autor questiona se é "machado" ou “enxó”. 


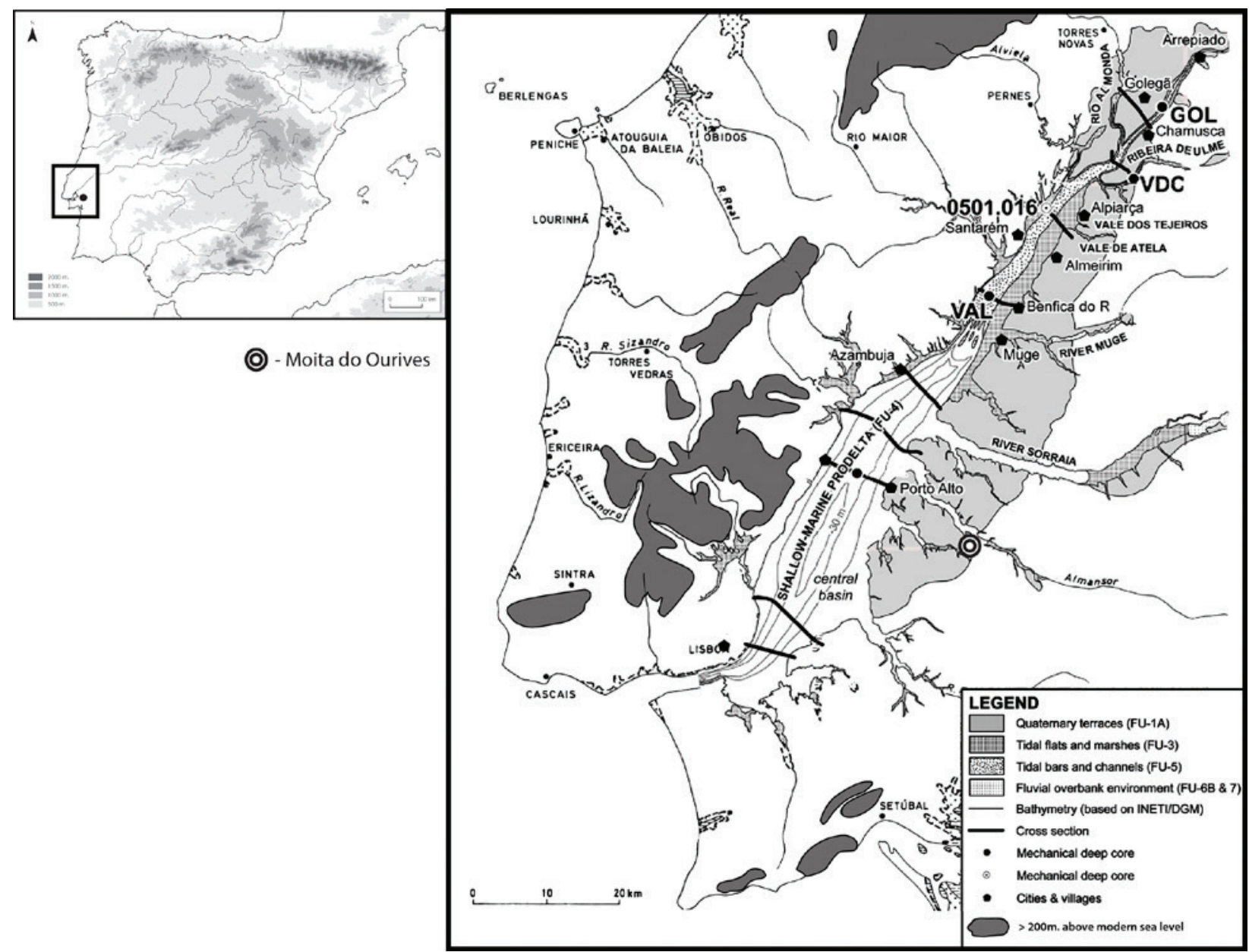

Figura 1 - Localização da Moita do Ourives na Península Ibérica e no paleoestuário existente no Holocénico Médio no Baixo Vale do Tejo (c. 500o-400o cal BC). (base cartográfica: Daveau, [1980, fig.6] e Vis, et al. [2008, fig.12] - adaptado; ideia retirada de Carvalho [2014, fig. 6.2]).

\section{Pedra polida, afeiçoada e com traços de utilização} Relação categoria tipológica / matéria-prima

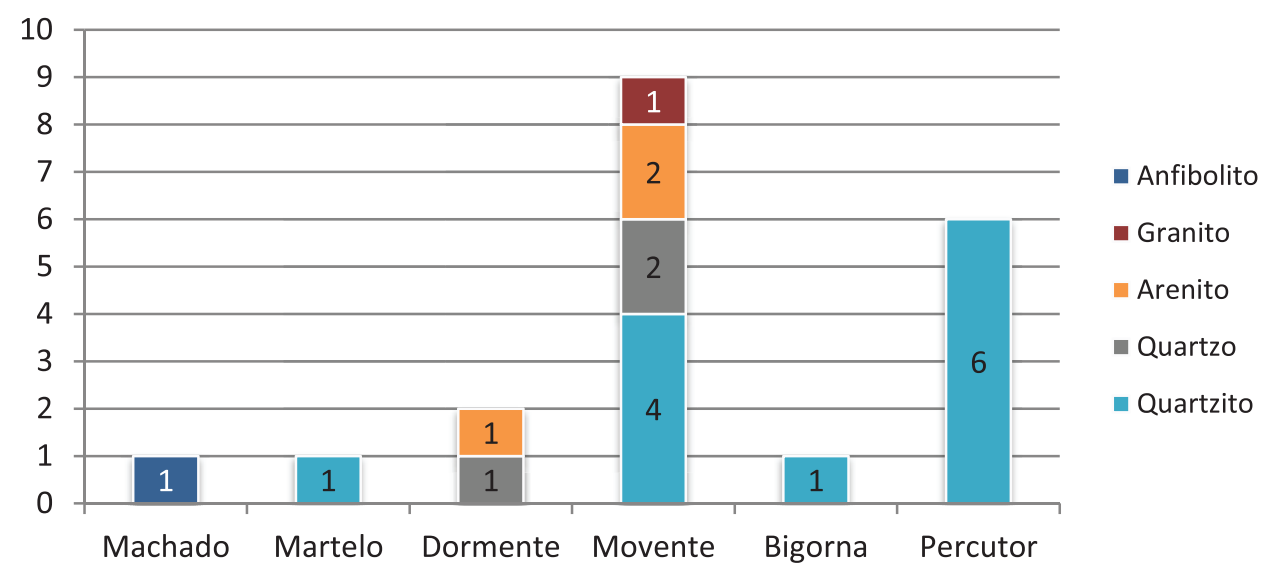

Figura 2 - Pedra polida, afeiçoada e com traços de utilização da Moita do Ourives. Relação categoria tipológica / matéria-prima. 

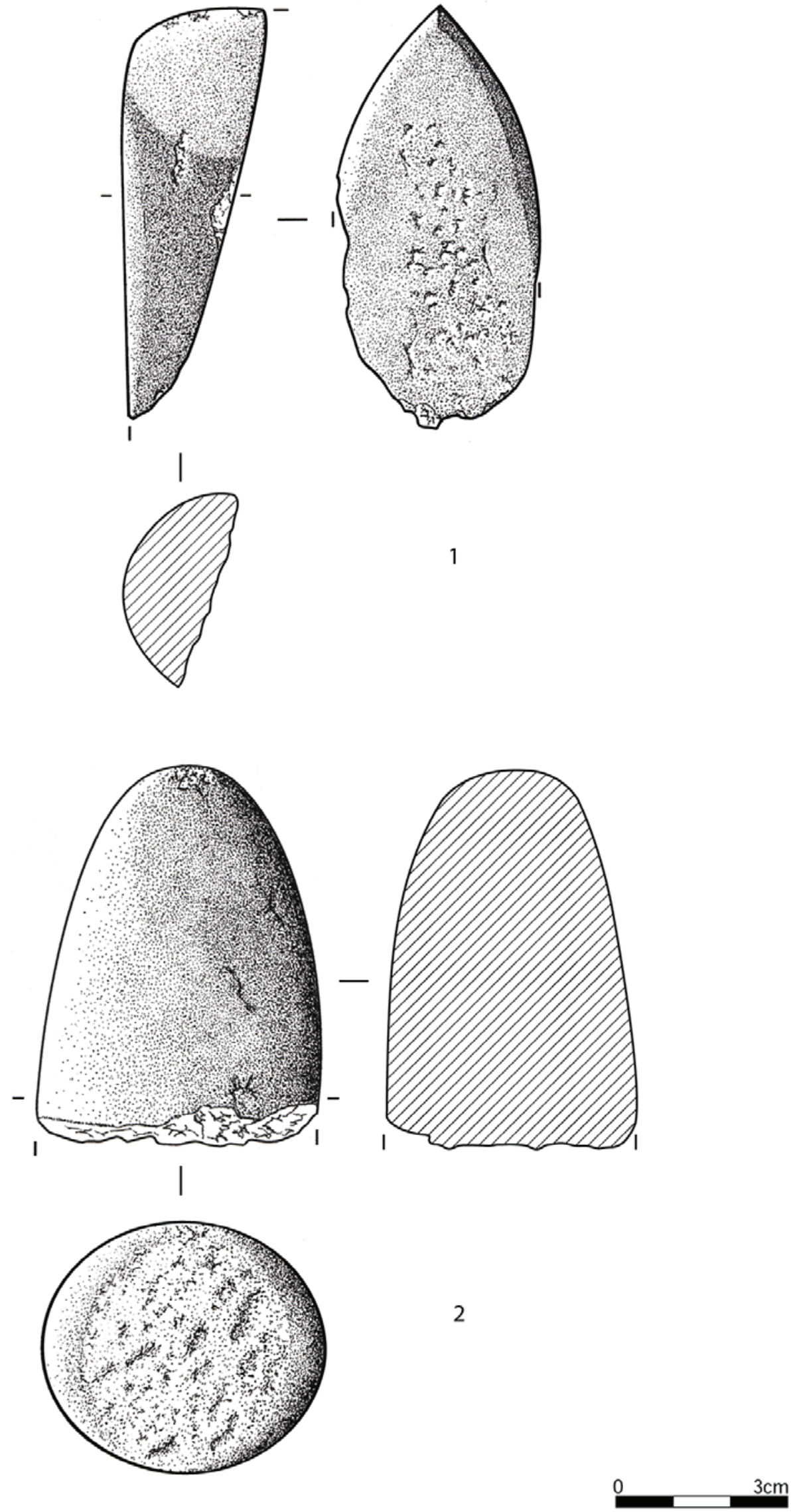

Figura 3 - Moita do Ourives. Pedra polida: 1- Machado; 2 - Martelo. 

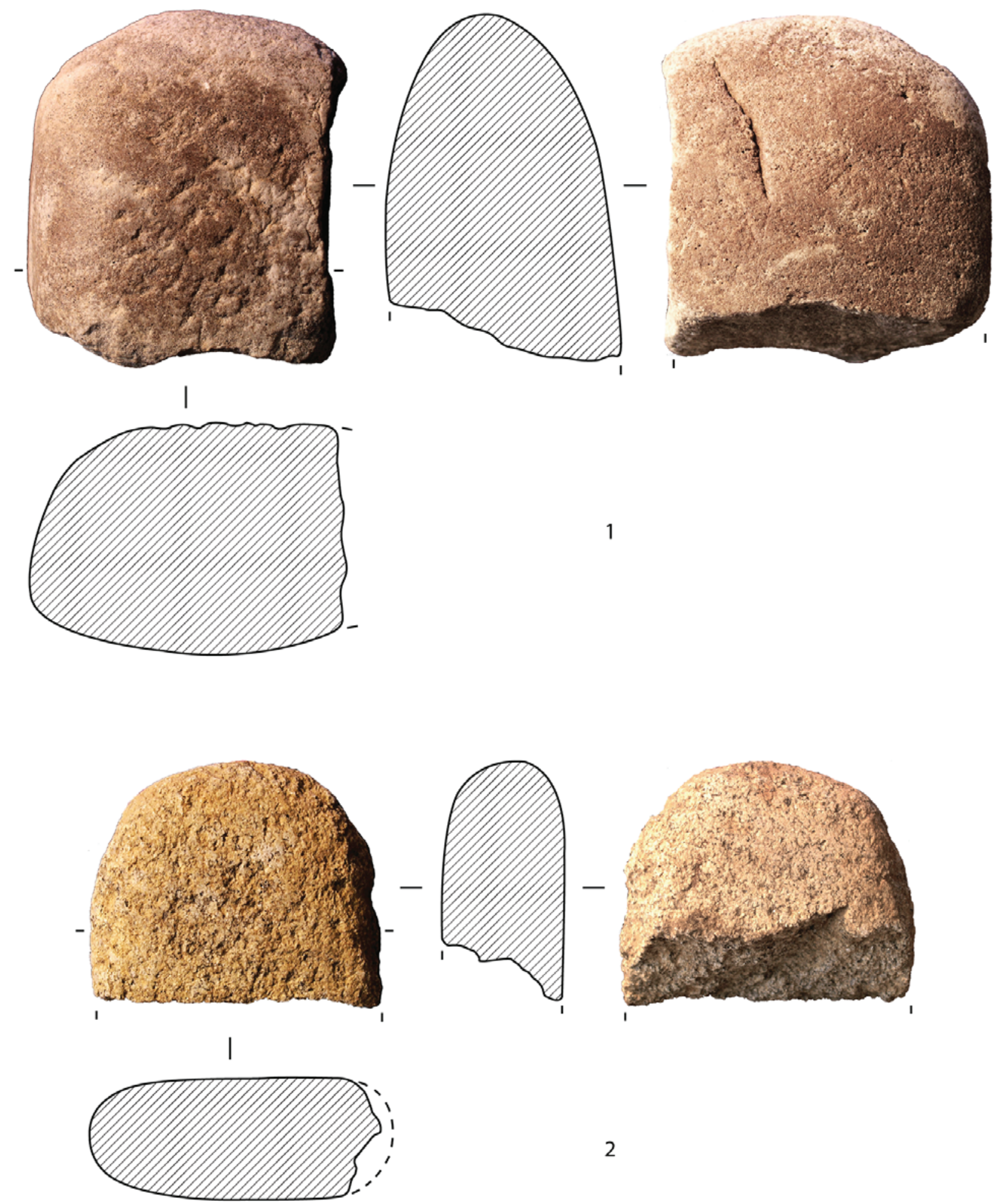

Figura 4 - Moita do Ourives. Pedra afeiçoada: 1 - Movente em quartzito; 2 - Movente em granito. 


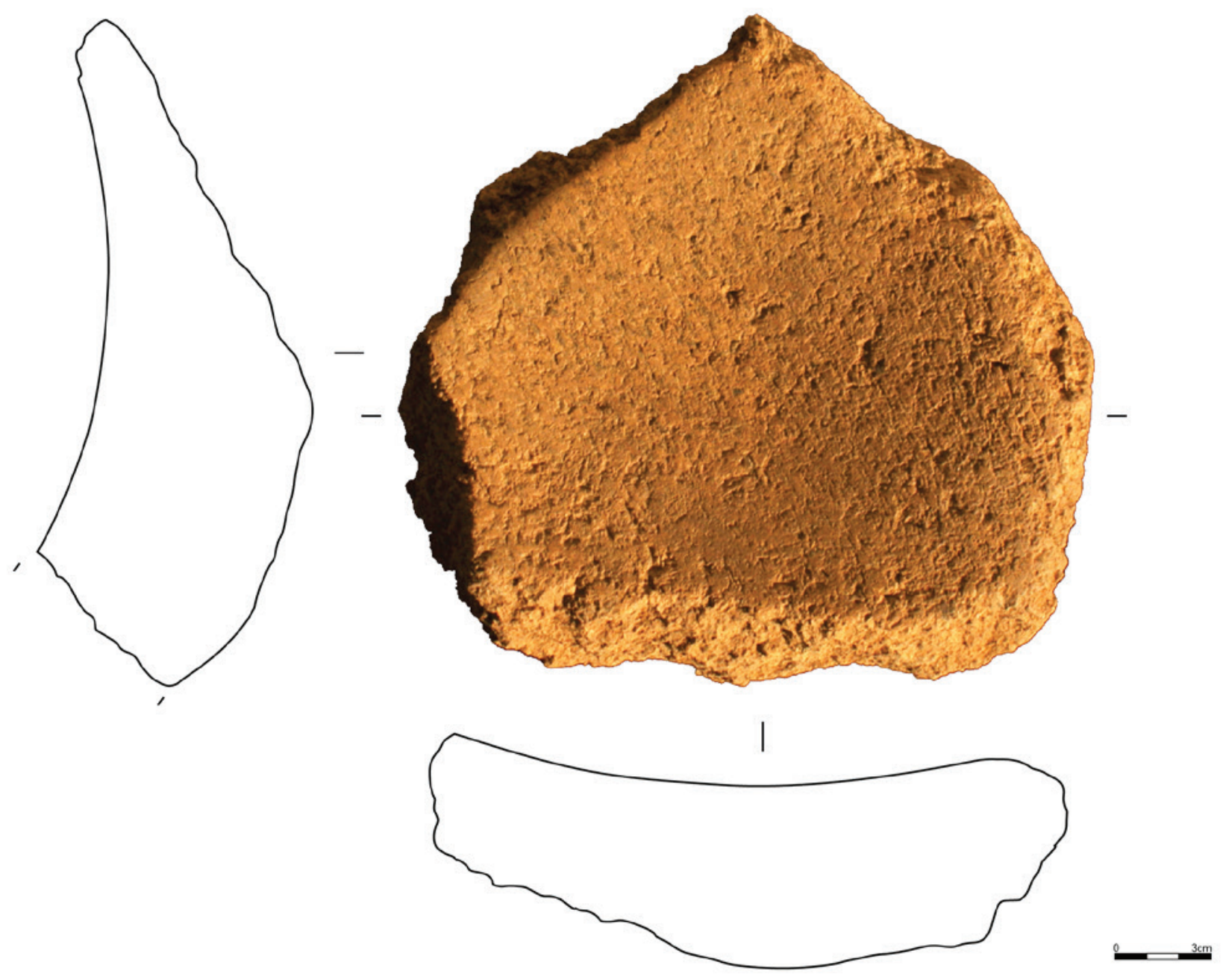

Figura 5-Moita do Ourives. Pedra afeiçoada: Dormente. 

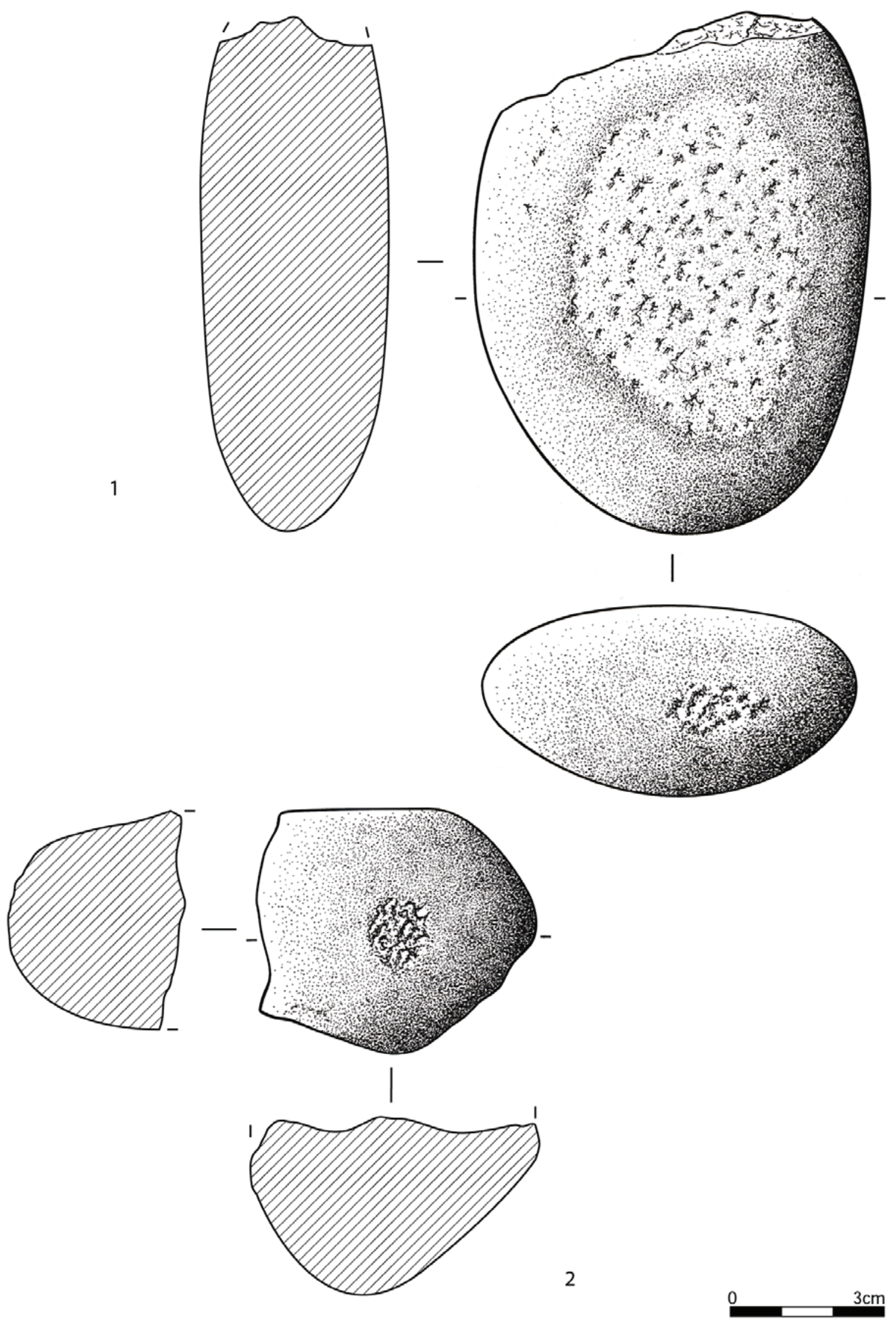

Figura 6 - Moita do Ourives. Pedra afeiçoada em quartzito: 1 - Percutor/Movente; 2 - Percutor (com fractura térmica). 


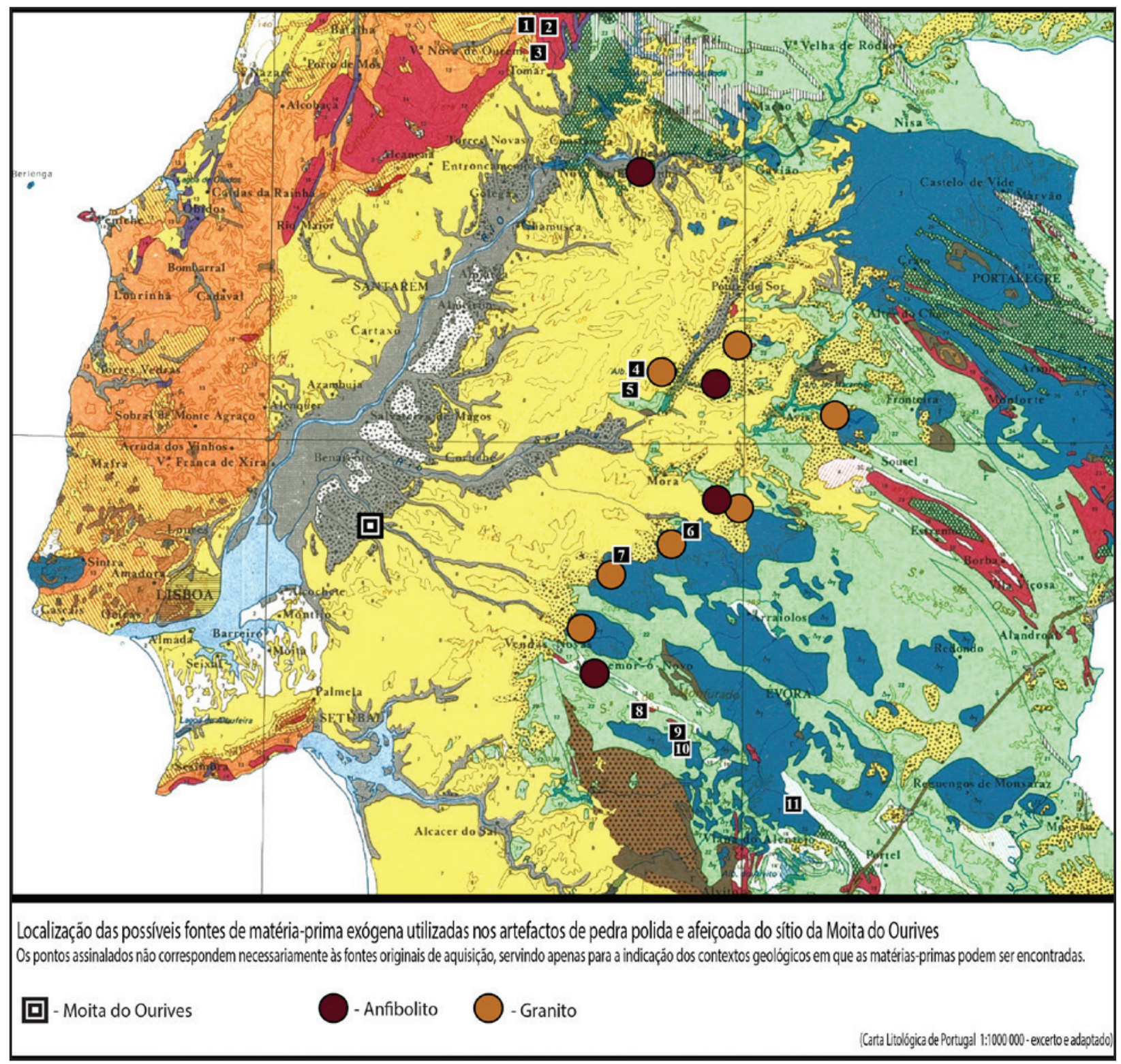

Figura 7 - Localização das possíveis fontes de matéria-prima exógena (granito e anfibolito), face à Moita do Ourives, e de ocupações atribuíveis ao Neolítico médio na sua envolvência. (base cartográfica: Carta Litológica de Portugal 1: 1000 ooo). Legenda: 1 - Gruta dos Ossos; 2 - Cadaval; 3 - Caldeirão; 4-Bernardo 1; 5-Alminho 1; 6 - Cabeceira 4; 7 - Cabeço da Areia; 8 - Escoural; 9 - Vale Rodrigo 3; 10 - Vale Rodrigo 2; 11 - Hortinha 1. 



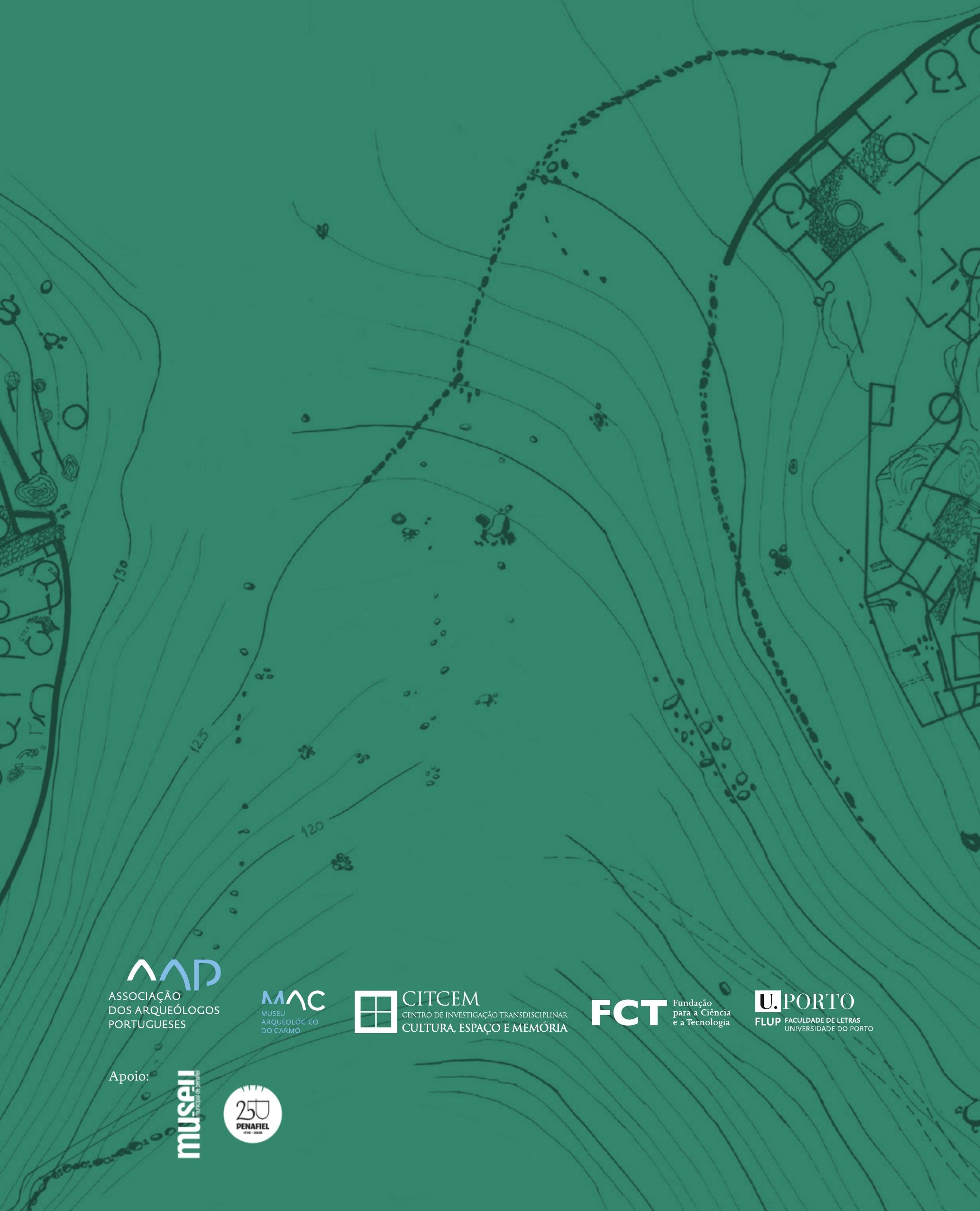

